Prepared in cooperation with the U.S. Army Corps of Engineers and Federal Emergency Management Agency

\title{
Flood-Frequency Comparison from 1995 to 2016 and Trends in Peak Streamflow in Arkansas, Water Years 1930-2016
}

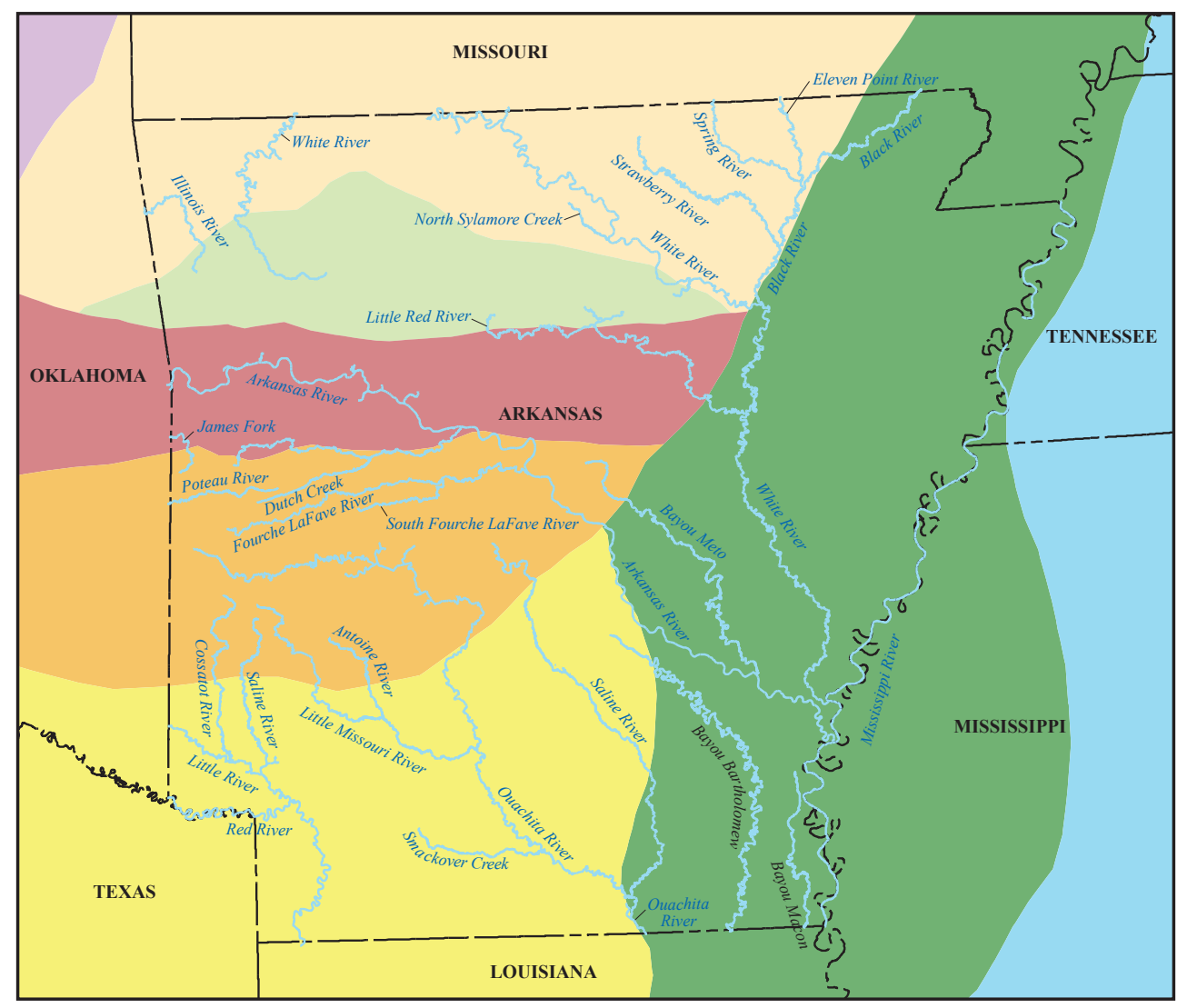

Scientific Investigations Report 2019-5131 
Cover. Physiographic sections in Arkansas and surrounding States (modified from figure 1). 


\section{Flood-Frequency Comparison from 1995 to 2016 and Trends in Peak Streamflow in Arkansas, Water Years 1930-2016}

By Paul A. Ensminger and Brian K. Breaker

Prepared in cooperation with the U.S. Army Corps of Engineers and Federal

Emergency Management Agency

Scientific Investigations Report 2019-5131 


\title{
U.S. Department of the Interior DAVID BERNHARDT, Secretary
}

\author{
U.S. Geological Survey \\ James F. Reilly II, Director
}

U.S. Geological Survey, Reston, Virginia: 2019

For more information on the USGS - the Federal source for science about the Earth, its natural and living resources, natural hazards, and the environment-visit https://www.usgs.gov or call 1-888-ASK-USGS.

For an overview of USGS information products, including maps, imagery, and publications, visit https://store.usgs.gov.

Any use of trade, firm, or product names is for descriptive purposes only and does not imply endorsement by the U.S. Government.

Although this information product, for the most part, is in the public domain, it also may contain copyrighted materials as noted in the text. Permission to reproduce copyrighted items must be secured from the copyright owner.

Suggested citation:

Ensminger, P.A., and Breaker, B.K., 2019, Flood-frequency comparison from 1995 to 2016 and trends in peak streamflow in Arkansas, water years 1930-2016: U.S. Geological Survey Scientific Investigations Report 2019-5131, 20 p., https://doi.org/10.3133/sir20195131.

ISSN 2328-0328 (online) 


\section{Contents}

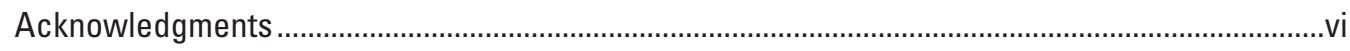

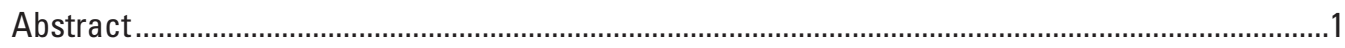

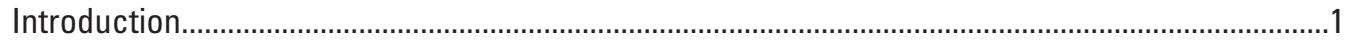

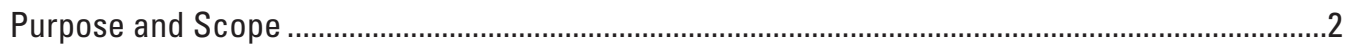

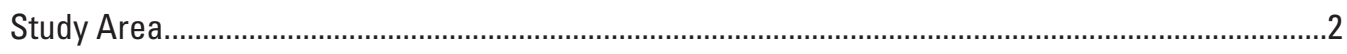

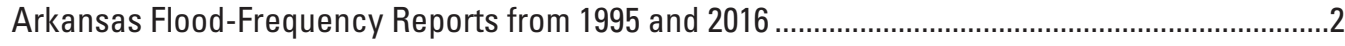

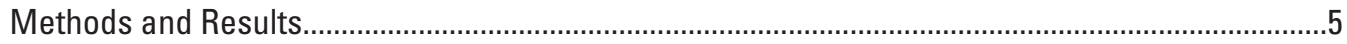

Mann-Kendall Tau Test for Trends in Peak Streamflows ..........................................................5

Locally Estimated Scatterplot Smoothing of Peak Streamflows ..............................................5

One-Percent Annual Exceedance Probability Changes through Time ......................................5

Arkansas Regional Regression Equations Comparison .......................................................... 9

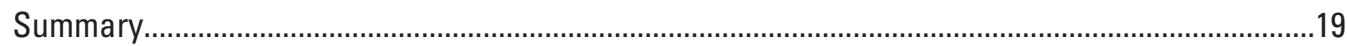

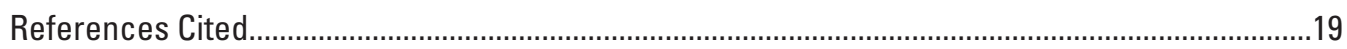




\section{Figures}

1. Map showing locations of the 15 selected streamgages and physiographic sections in Arkansas and surrounding States

2. Map showing food regions and 74 selected locations where the 2016 and 1995 annual exceedance probability floods were computed.

3. Graphs showing locally estimated scatterplot smoothing trend lines of the annual peak streamflow data at the 15 selected streamgages for the full period of record

4. Graphs showing the 1-percent annual exceedance probability flood trend for the 15 selected streamgages plotted with the annual peak for the full period of record .....11

5. Graph showing relation between the log base 10 transformed recurrence interval and the average percentage difference change between the 2016 and 1995 annual exceedance probability flood estimates for the 74 streamflow locations representing 15 streamgages and the $0-, 10-, 50-$, and 85-percent locations along the stream, terminating at the Arkansas border.

6. Boxplots showing the range of percentage differences of annual exceedance probability flood estimates from the 1995 to the 2016 regional regression equations by peak streamflow region as designated by Wagner and others (2016)

\section{Tables}

1. The 15 selected streamgages and the associated Mann-Kendall trend results with probability values for the designated period of record

2. The 15 selected streamgages used in this study and the percentage differences from the initial 1-percent annual exceedance probability flood estimate for each subsequent 1-percent annual exceedance probability flood reevaluation.

3. The percentage difference between the 2016 and 1995 annual exceedance probability floods for the 74 selected streamflow locations, which include the 15 selected streamgage locations and the $0-, 10-, 50-$, and 85 -percent locations along each of the selected streams, terminating at the Arkansas border, when applicable. 


\title{
Conversion Factors
}

U.S. customary units to International System of Units

\begin{tabular}{|c|c|c|}
\hline Multiply & By & To obtain \\
\hline \multicolumn{3}{|c|}{ Length } \\
\hline inch (in.) & 2.54 & centimeter $(\mathrm{cm})$ \\
\hline inch (in.) & 25.4 & millimeter (mm) \\
\hline \multicolumn{3}{|c|}{ Flow rate } \\
\hline cubic foot per second $\left(\mathrm{ft}^{3} / \mathrm{s}\right)$ & 0.02832 & cubic meter per second $\left(\mathrm{m}^{3} / \mathrm{s}\right)$ \\
\hline
\end{tabular}

\section{Datum}

Vertical coordinate information is referenced to the North American Vertical Datum of 1988 (NAVD 88).

Horizontal coordinate information is referenced to the North American Datum of 1983 (NAD 83).

Altitude, as used in this report, refers to distance above the vertical datum.

\section{Supplemental Information}

A water year is the period from 0ctober 1 to September 30 and is designated by the year in which it ends; for example, water year 2015 was from October 1, 2014, to September 30, 2015.

\section{Abbreviations}

\author{
AEP annual exceedance probability \\ AEPF annual exceedance probability flood \\ EMA Expected Moments Algorithm \\ LOESS locally estimated scatterplot smoothing \\ PD percentage difference \\ RI recurrence interval \\ RRE regional regression equation \\ USGS U.S. Geological Survey
}




\section{Acknowledgments}

Thanks to the U.S. Army Corps of Engineers and the Federal Emergency Management Agency, whose valuable support made this report possible.

Thanks to Maxwell Lindaman, Hydrologist, U.S. Geological Survey, for his geographic information system help in generating report figures. 


\title{
Flood-Frequency Comparison from 1995 to 2016 and Trends in Peak Streamflow in Arkansas, Water Years 1930-2016
}

\author{
By Paul A. Ensminger and Brian K. Breaker
}

\section{Abstract}

In 2016, the U.S. Geological Survey, in cooperation with the U.S. Army Corps of Engineers and the Federal Emergency Management Agency, began a study in Arkansas to investigate possible increasing trends in annual peak streamflow data and the possible resulting increase in the annual exceedance probability flood (AEPF) predictions. Temporal trends of peak streamflow were investigated at 15 selected streamgages on unregulated streams in Arkansas having 30 or more years of peak streamflow data through the 2016 water year. For the period of record at each streamgage, the Mann-Kendall trend test indicated that 14 of the 15 streamgages had no statistically significant peak streamflow trends and 1 streamgage had a statistically significant decreasing peak streamflow trend. Visual examination of the locally estimated scatterplot smoothing technique trend lines of the peak streamflow data indicated a possible increasing peak streamflow trend at 8 of the 15 streamgages since the 1990s.

A sequential series analysis of the 1-percent AEPF at each of the 15 selected streamgages was completed by selecting an initial subset of the oldest peak streamflow data from each site to estimate the initial 1-percent AEPF. This initial peak streamflow data subset was subsequently appended with 10 -year increments of additional peak streamflow data until the full period of peak streamflow data was analyzed. The maximum increase in the 1-percent AEPF was 113 percent, and the maximum decrease was 31.9 percent.

Percentage differences between the AEPFs derived from regional regression equations presented in the 1995 and 2016 Arkansas flood-frequency reports were compared. The average percentage differences for the 74 selected locations indicate that the 4-, 2-, 1-, and 0.2-percent AEPFs computed using the 2016 regional regression equations were higher by $3.52,5.10,8.59$, and 13.31 percent, respectively (25-, 50-, $100-$, and 500-year recurrence interval floods), than the same percentage AEPFs computed using the 1995 regional regression equations. The average percentage differences between the 1995 and 2016 AEPFs for the 10-percent AEPF (10-year recurrence interval flood) resulted in 2016 AEPF predictions being 0.41 percent higher. For the 50- and 20-percent AEPFs (2- and 5-year recurrence interval floods), the 2016 AEPFs were less than the 1995 AEPFs by 2.53 and 0.31 percent, respectively.

\section{Introduction}

Significantly increasing peak streamflow trends are of concern to local, State, and Federal agencies in Arkansas because of the corresponding increased flood risk to highway structures and surrounding communities. The risk of flooding can be characterized by annual exceedance probability flood (AEPF) predictions, which are developed from peak streamflow data and flood-frequency analysis. Transportation and drainage infrastructure, such as bridges, culverts, channels, canals, dams, and levees, generally is designed and operated under the assumption of stationarity (Milly and others, 2008), which implies that natural and anthropogenic-induced changes are too small to significantly affect statistical characteristics like annual peak streamflow (Walter and Vogel, 2010). However, substantial natural and anthropogenic changes might result in significant trends within the annual peak streamflow data.

When completing flood-frequency analyses, the peak streamflow data are assumed to be stationary and their statistical properties are unchanged over time, according to Bulletin 17B, "Guidelines for Determining Flood Flow Frequency" (Interagency Committee on Water Data, 1982). However, stationary and nonstationary peak streamflow data are effectively indistinguishable because of the paucity of observation records except where changes in the underlying processes are so dramatic that no statistical assessment is necessary (Lins and Cohn, 2011). Additionally, there can be multidecadal and century-scale variation in streamflow lending to multiyear periods in those records that may indicate uptrends and downtrends and, thus, are not necessarily indicative of a persistent change in the system (Cohn and Lins, 2005).

Hirsch (2011) denoted the importance of frequent updates to flood-frequency analyses to assist water-resources management in the design of structures that are dependent on the hydrologic variables that result from these analyses. In Arkansas, the two most recent flood-frequency reports were published in 1995 (Hodge and Tasker, 1995) and 2016 (Wagner and others, 2016) and documented the regional regression 
equations (RREs) used to calculate the 50-, 20-, 10-, 4-, 2-, 1-, and 0.2-percent AEPFs. The U.S. Geological Survey (USGS), in cooperation with the U.S. Army Corps of Engineers and the Federal Emergency Management Agency, completed a study to determine if significant increasing trends exist in annual peak streamflow data from Arkansas and to compare the percentage differences (PDs) of the AEPF estimates from the two most recently published flood-frequency reports for Arkansas.

\section{Purpose and Scope}

This report presents (1) an analysis of trends within peak streamflow data for 15 selected streamgage sites in Arkansas and (2) the PDs between the 1995 and 2016 Arkansas AEPFs for the 50-, 20-, 10-, 4-, 2-, 1-, and 0.2-percent AEPFs at the 15 selected sites and at ungaged sites at the $0-, 10-, 50-$, and 85 -percent lengths of each of the 15 selected streams where those locations were within the boundaries of the State.

\section{Study Area}

The geographic scope of this report encompasses most of Arkansas (fig. 1). Arkansas is characterized by a diverse topography and contains parts of six physiographic sections: the Springfield-Salem Plateaus, Boston Mountains, Arkansas Valley, Ouachita Mountains, West Gulf Coastal Plain, and Mississippi Alluvial Plain (Wagner and others, 2016). The climate in Arkansas is mild and moderately humid. For the period 1951-2011, mean annual precipitation for the State was 49.8 inches (in.) and ranged from 44 in. in the SpringfieldSalem Plateaus near the Missouri State line and the Arkansas Valley near the Oklahoma State line to 64 in. in the Ouachita Mountains (Pugh and Westerman, 2014).

\section{Arkansas Flood-Frequency Reports from 1995 and 2016}

Wagner and others (2016) used data collected through 2013 and the Expected Moments Algorithm (EMA) for fitting the Log-Pearson Type III distribution of the annual peak streamflow data that were used to estimate AEPFs (Cohn and others, 1997, 2001; Griffis and others, 2004). The use of the EMA method to estimate AEPF events was recommended by the Subcommittee on Hydrology as a revision to Bulletin 17B (Advisory Committee on Water Information, Subcommittee on Hydrology, Hydrologic Frequency Analysis Work Group, written commun., 2013). The EMA method applies the GrubbsBeck test to screen multiple potentially influential low floods that are not relevant to the processes associated with larger floods (Cohn and others, 2013). The EMA addresses several methodological concerns identified in Bulletin 17B while retaining the essential structure and moments-based approach procedures for determining flood frequency (Interagency Committee on Water Data, 1982). The EMA can accommodate interval data, which simplifies the analysis of datasets containing censored observations, historical and (or) paleo data, low outliers, and uncertain data points while also providing enhanced confidence intervals for the estimated streamflows (Veilleux and others, 2014). The 2016 report (Wagner and others, 2016) also incorporated an updated regional skew coefficient, which was developed for Arkansas using Bayesian weighted least-squares/generalized least-squares regression (Veilleux, 2009, 2011).

The 1995 Arkansas flood-frequency analysis (Hodge and Tasker, 1995) defined four flood regions and used data collected through 1993 from 204 streamgages to develop the RREs. In comparison, the 2016 Arkansas flood-frequency analysis (Wagner and others, 2016) documented five flood regions (dividing region $\mathrm{B}$ of the 1995 report into subregions B1 and B2; fig. 2) and used data collected through 2013 from 281 streamgages to develop RREs. The 1995 and 2016 RREs included some similar basin characteristics; however, the 2016 RREs typically included additional basin and climatic variables compared to the 1995 RREs. As a result, for the same streamflow location, the AEPF estimates from the 1995 (Hodge and Tasker, 1995) and 2016 (Wagner and others, 2016) flood-frequency reports may be different.

With respect to floods, the annual exceedance probability estimates the likelihood, in percent, of a specific magnitude flood occurring in any given year. For instance, a 1-percent AEPF is a flood with a 1-percent probability of occurring during any given year. Traditionally, AEPFs have been expressed as a recurrence interval (RI), in years, where 50-, 20-, 10-, 4-, 2-, 1-, 0.5-, and 0.2-percent AEPFs were reported as 2-, 5-, 10-, 25-, 50-, 100-, 200-, and 500-year RI floods, respectively (Holmes and Dinicola, 2010). In terms of probability of occurrence, this means there is a 1 in 100 chance (or 1-percent probability) that in any single year, the 100-year flood (1-percent AEPF) will occur at a given location. However, some have erroneously interpreted the " 100 -year flood" to mean that a flood of that magnitude would be expected to occur only once during a 100-year period. In fact, a 1-percent AEPF (100-year flood) has a 1-percent probability of occurring in any given year, regardless of past flooding events.

The probability $P$ that a flood with an annual exceedance probability, in percent, will occur at least once in an $\mathrm{N}$-year period is shown in the following equation:

$$
P=\left(1-[1-(A E P)]^{N}\right)
$$

where
$P \quad$ is the probability of the annual exceedance probability (AEP) flood occurring over $N$-year period;
$A E P \quad$ is the annual exceedance probability, in percent; and
$N \quad$ is the number of years.




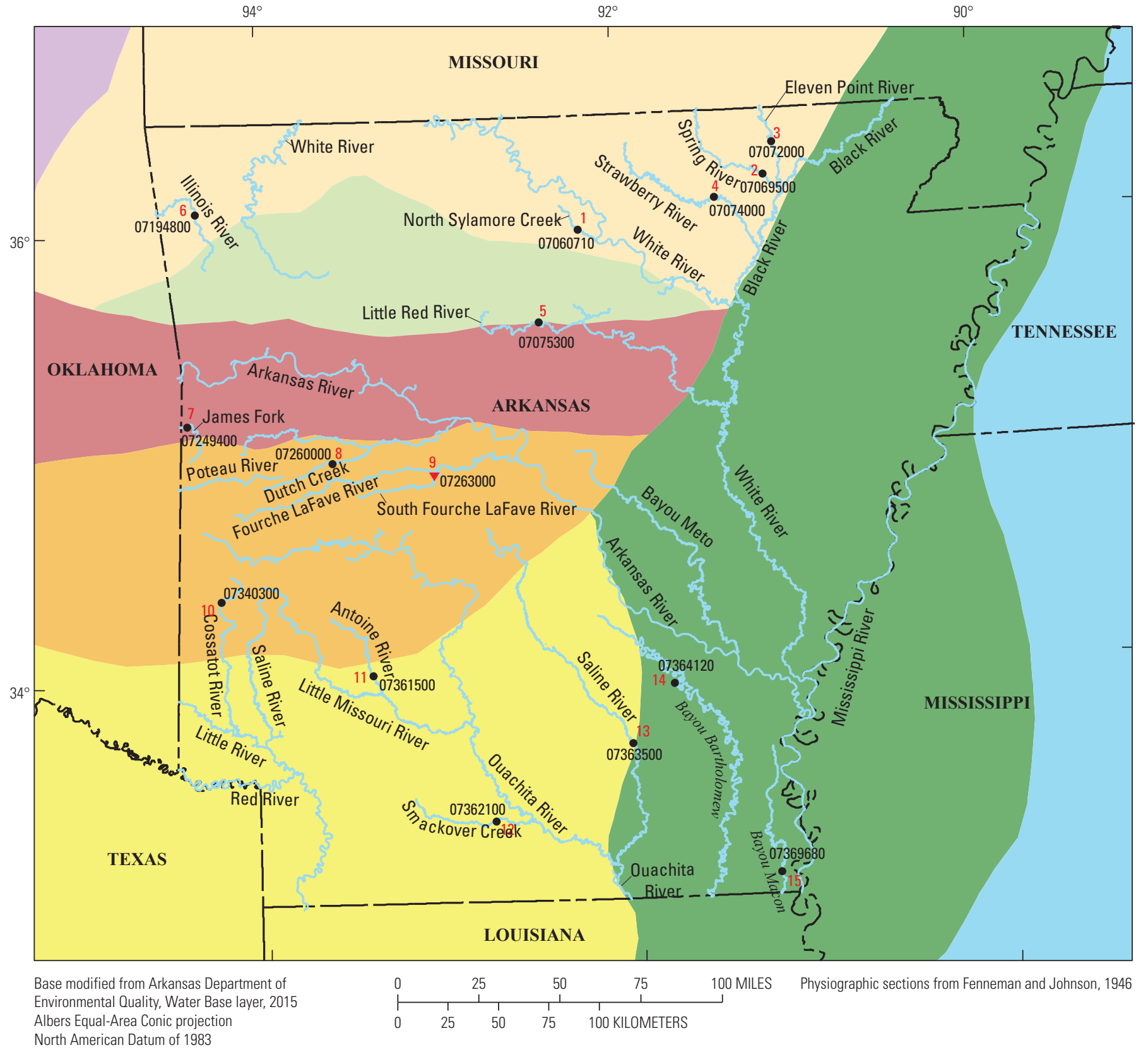

North American Datum of 1983

\section{EXPLANATION}

Physiographic sections

Osage Plains

Arkansas Valley

Boston Mountains

East Gulf Coastal Plain
Mississippi Alluvial Plain

Ouachita Mountains

Springfield-Salem Plateaus

West Gulf Coastal Plain

$\begin{array}{cl} & \text { Trend at site } \\ & \text { Decreasing } \\ \bullet & \text { No trend } \\ 07369680 & \text { U.S. Geologic Survey station number } \\ 15 & \text { Site number (see table 1) }\end{array}$

Figure 1. Locations of the 15 selected streamgages and physiographic sections in Arkansas and surrounding States. 


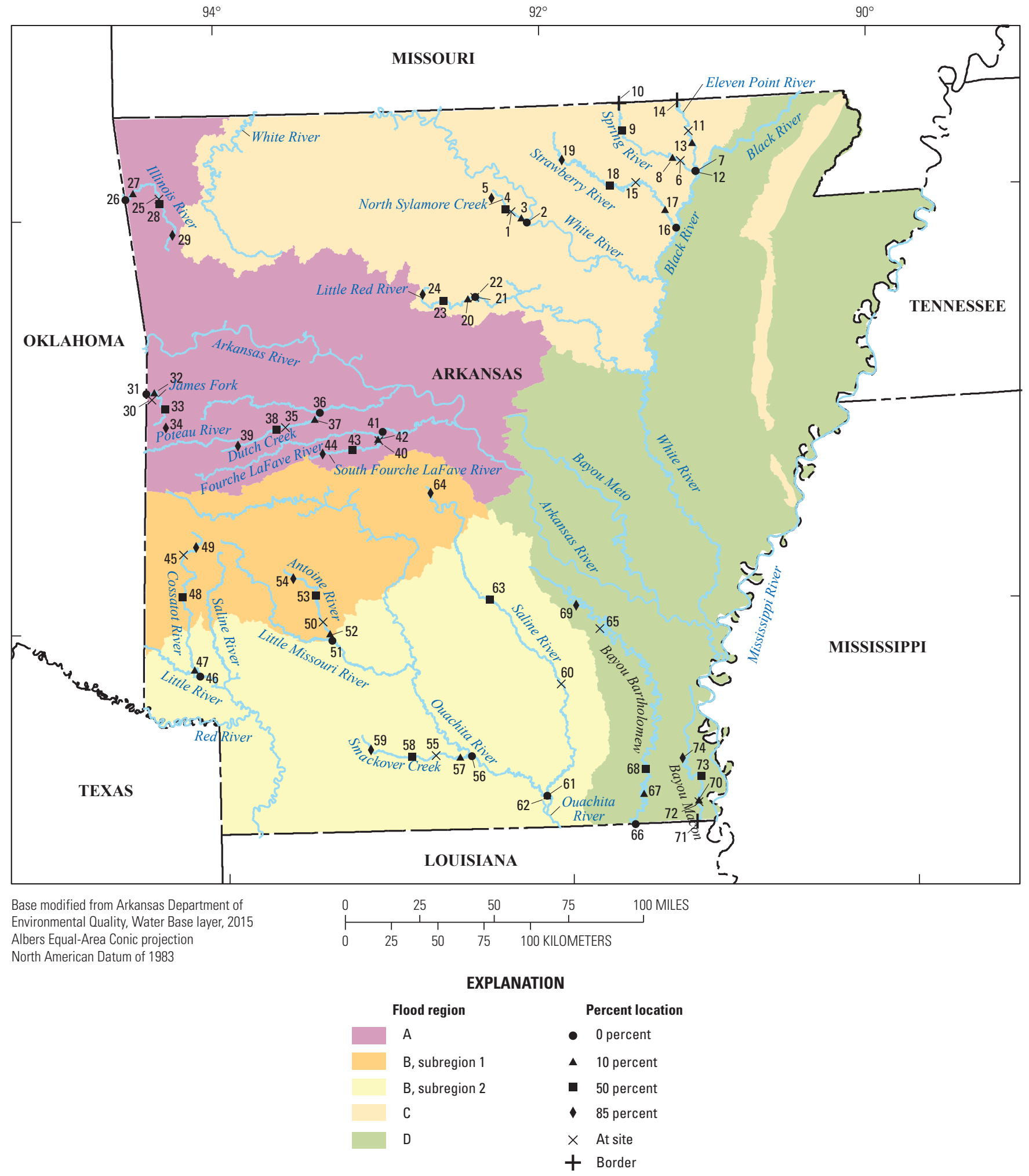

Figure 2. Flood regions (Wagner and others, 2016) and 74 selected locations where the 2016 and 1995 annual exceedance probability floods were computed. The 74 locations represent the 15 streamgages and the ungaged sites at the $0-, 10-, 50-$, and 85-percent lengths along each of the 15 streams, terminating at the Arkansas border. 
Using equation 1, a 1-percent AEP flood actually has a 26-percent probability of occurring within a 30 -year period $\left\{P=\left(1-[1-(0.01)]^{30}\right)\right\}$.

\section{Methods and Results}

The following sections describe the methods used to identify significantly increasing peak streamflow trends in Arkansas streams. The Mann-Kendall trend test and the locally estimated scatterplot smoothing (LOESS) technique were used to detect trends in the peak streamflow data at 15 selected streamgages for the period of 1930-2016. Temporal changes of the 1-percent AEPF that were attributed to the additional peak streamflow data resulting from increasing the period of record analyzed were investigated. In addition, the PDs in the 1-percent AEPFs derived using RREs from Hodge and Tasker (1995) and Wagner and others (2016) for 74 selected locations along 15 streams were compared for various annual exceedance probabilities, and the average PDs by flood region were analyzed. All streamflow data are publicly available from the USGS National Water Information System database (U.S. Geological Survey, 2016).

\section{Mann-Kendall Tau Test for Trends in Peak Streamflows}

Hydrologic data commonly have a nonnormal distribution, which means that statistical tests assuming an underlying normal distribution can be inadequate for trend detection (Kundzewicz and Robson, 2004). The nonparametric MannKendall trend test assumes no underlying distribution and tests for the likelihood of an increasing or decreasing temporal peak streamflow trend. Annual peak streamflow data that were available for the 15 selected streamgages through the 2016 water year were analyzed for trends using the MannKendall trend test. The Mann-Kendall trend test was used to compute the monotonic relation between peak streamflow and water year (Helsel and Hirsch, 2002) and resulted in a Kendall's tau coefficient that indicated the direction of the trend and the significance level or probability value ( $p$-value). In this analysis, a trend was considered statistically significant if the $p$-value was less than or equal to 5 percent. Excluding the historic peak streamflow events and using the available peak streamflow record through 2016 for each streamgage, the $p$-value resulting from the Mann-Kendall trend test indicated 14 of the 15 selected streamgages had no statistically significant trends and 1 streamgage had a significant decreasing trend (fig. 1, table 1) as indicated from the $p$-value ( $p$-values less than or equal to 0.05 ) and the negative value of Kendall's tau.

\section{Locally Estimated Scatterplot Smoothing of Peak Streamflows}

LOESS is a nonparametric regression technique for estimating regression surfaces (Cleveland and others, 1988, 1992) by smoothing a curve through a scatterplot and providing a visual representation of the trend pattern. For this study, the smoothing function attempts to capture the general patterns in the peak streamflow versus water-year relation. The LOESS trend line indicates the central tendency of the peak streamflow data with respect to water year and was evaluated using the LOESS function in R (R Core Team, 2016). The primary parameter affecting the smoothness of the fit is the span or window width. The span parameter controls how the data nearest to a specific point are weighted, and it affects the LOESS fit through that specific point. The selection of the span is determined subjectively according to the purpose of smoothing (Helsel and Hirsch, 2002). In this study, all LOESS trend lines were plotted using a span parameter of 0.75 . Visual examination of LOESS trend line plots (fig. 3) indicated an increasing streamflow trend starting from the 1990s to the ending year for the period of record for eight streamgages (sites 1-3, 5, 7-8, 10, and 13 in fig. 1, fig. 3, and table 1). A similar trend could not be observed for site 14, Bayou Bartholomew near Star City (USGS station 07364120; table 1), because the period of record at that site ended in 1980.

\section{One-Percent Annual Exceedance Probability Changes through Time}

All annual peak streamflow events at a streamgage location throughout time are referred to as the "population" of peak streamflow data. The term "sample" refers to a part of this population that is representative of the population from which it was selected. The USGS peak streamflow data are "samples" of peak streamflow at a streamgage location. The length of a peak streamflow record used to estimate the 1-percent AEPF affects the accuracy and confidence limits in the estimates, and AEPF estimates become more accurate as the length of a peak streamflow record increases. In a shortterm (10 to 20 years of annual peak streamflow data) record, the extreme peak streamflow events substantially affect the 1-percent AEPF statistics; however, as the length of the peak streamflow record increases, these extreme peak streamflow events have less effect, so the accuracy and confidence in the 1-percent AEPF estimates increases.

To evaluate temporal changes to the AEPF at streamgages, the 1-percent AEPFs (100-year RI floods) were calculated by sequentially apportioning the peak streamflow data from a short period-of-record segment to a longer segment and reevaluating the 1-percent AEPF using each longer segment. The initial 1-percent AEPF was derived from a 10- to 
Table 1. The 15 selected streamgages and the associated Mann-Kendall trend results with probability $(p)$ values for the designated period of record.

[ $p$-values less than or equal to 0.05 are considered significant, and streamgages with significant trends are shaded in gray; USGS, U.S. Geological Survey; DA, contributing drainage area; $\mathrm{mi}^{2}$, square mile; NPFSY, number of streamflow peaks (historic peak streamflow removed from trend analysis)]

\begin{tabular}{|c|c|c|c|c|c|c|c|c|c|}
\hline \multirow{2}{*}{$\begin{array}{c}\text { Site } \\
\text { number } \\
\text { (fig. 1) }\end{array}$} & \multirow{2}{*}{$\begin{array}{l}\text { USGS station } \\
\text { number } \\
\text { (fig. 1) }\end{array}$} & \multirow[b]{2}{*}{ USGS streamgage name } & \multirow{2}{*}{$\begin{array}{l}\text { Period } \\
\text { of record } \\
\text { analyzed }\end{array}$} & \multirow{2}{*}{$\begin{array}{c}\text { DA } \\
\left(\mathrm{mi}^{2}\right)\end{array}$} & \multirow[b]{2}{*}{ Latitude } & \multirow[b]{2}{*}{ Longitude } & \multirow[b]{2}{*}{ NPFSY } & \multicolumn{2}{|c|}{ Mann-Kendall } \\
\hline & & & & & & & & Tau & $p$-value \\
\hline 1 & 07060710 & $\begin{array}{l}\text { North Sylamore Creek near Fifty } \\
\text { Six, Arkansas }\end{array}$ & 1966-2016 & 58.1 & 35.992 & -92.214 & 50 & 0.145 & 0.139 \\
\hline 2 & 07069500 & $\begin{array}{l}\text { Spring River at Imboden, } \\
\text { Arkansas }\end{array}$ & $1937-2016$ & 1,180 & 36.206 & -91.172 & 80 & 0.059 & 0.445 \\
\hline 4 & 07074000 & $\begin{array}{l}\text { Strawberry River near Poughkeep- } \\
\text { sie, Arkansas }\end{array}$ & $1937-2015$ & 473 & 36.111 & -91.449 & 79 & -0.007 & 0.933 \\
\hline 5 & 07075300 & $\begin{array}{l}\text { South Fork of Little Red River at } \\
\text { Clinton, Arkansas }\end{array}$ & $1962-2016$ & 149 & 35.587 & -92.451 & 55 & 0.075 & 0.425 \\
\hline 9 & 07263000 & $\begin{array}{l}\text { South Fourche LaFave River near } \\
\text { Hollis, Arkansas }\end{array}$ & $1942-2014$ & 210 & 34.912 & -93.056 & 73 & -0.207 & 0.010 \\
\hline 10 & 07340300 & $\begin{array}{l}\text { Cossatot River near } \\
\text { Vandervoort, Arkansas }\end{array}$ & 1968-2016 & 89.6 & 34.380 & -94.236 & 49 & -0.023 & 0.823 \\
\hline 11 & 07361500 & $\begin{array}{l}\text { Antoine River at Antoine, } \\
\text { Arkansas }\end{array}$ & $1951-2016$ & 178 & 34.039 & -93.418 & 65 & 0.077 & 0.365 \\
\hline 12 & 07362100 & $\begin{array}{l}\text { Smackover Creek near Smackover, } \\
\text { Arkansas }\end{array}$ & 1939-2016 & 385 & 33.375 & -92.777 & 78 & 0.003 & 0.976 \\
\hline 13 & 07363500 & Saline River near Rye, Arkansas & $1938-2016$ & 2,100 & 33.701 & -92.025 & 79 & -0.053 & 0.495 \\
\hline 14 & 07364120 & $\begin{array}{l}\text { Bayou Bartholomew near Star } \\
\text { City, Arkansas }\end{array}$ & $1942-80$ & 215 & 33.961 & -91.785 & 32 & -0.044 & 0.733 \\
\hline
\end{tabular}


Site 1, 07060710, North Sylamore Creek near Fifty Six, Arkansas

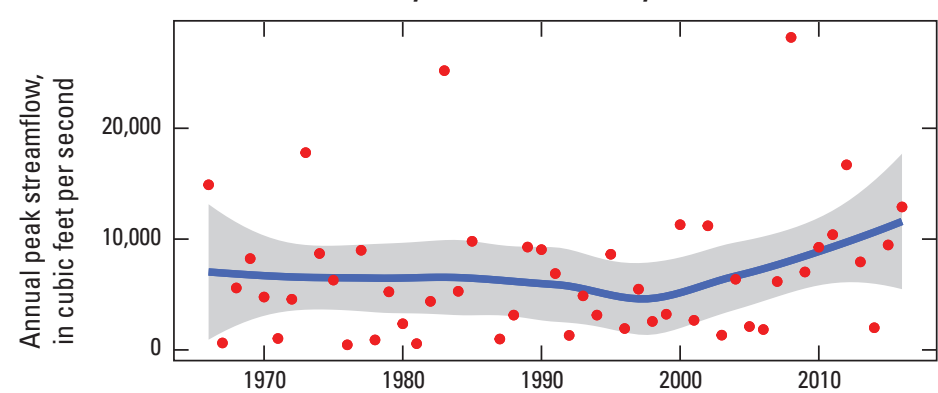

Site 3, 07072000, Eleven Point River near Ravenden Springs, Arkansas

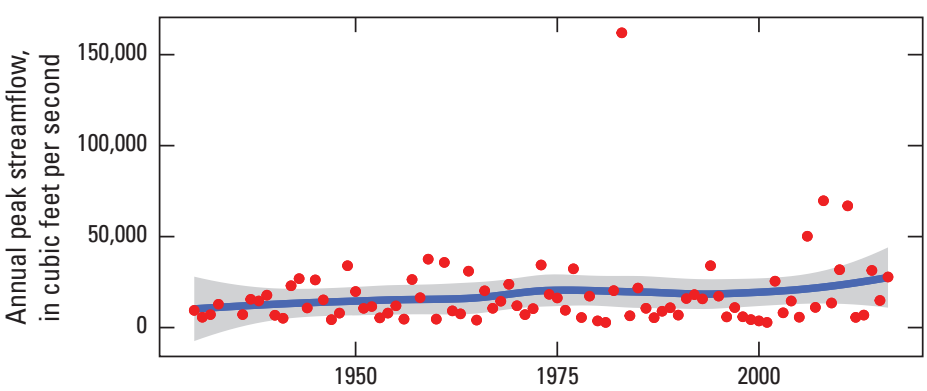

Site 5, 07075300, South Fork of Little Red River at Clinton, Arkansas

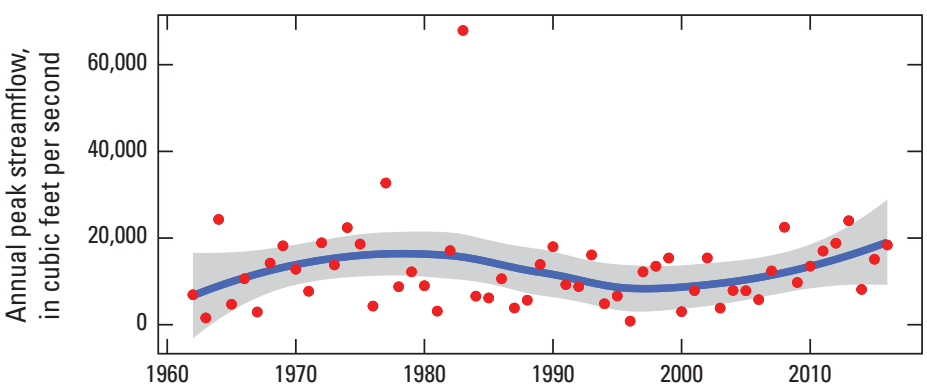

Site 7, 07249400, James Fork near Hackett, Arkansas

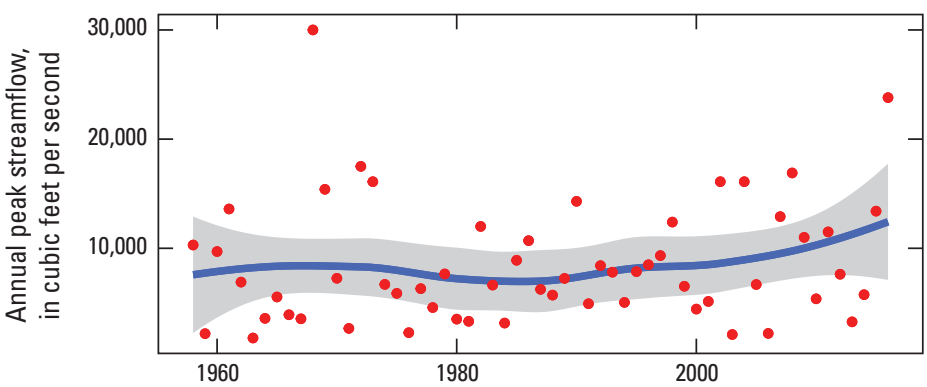

Site 9, 07263000, South Fourche LaFave River near Hollis, Arkansas

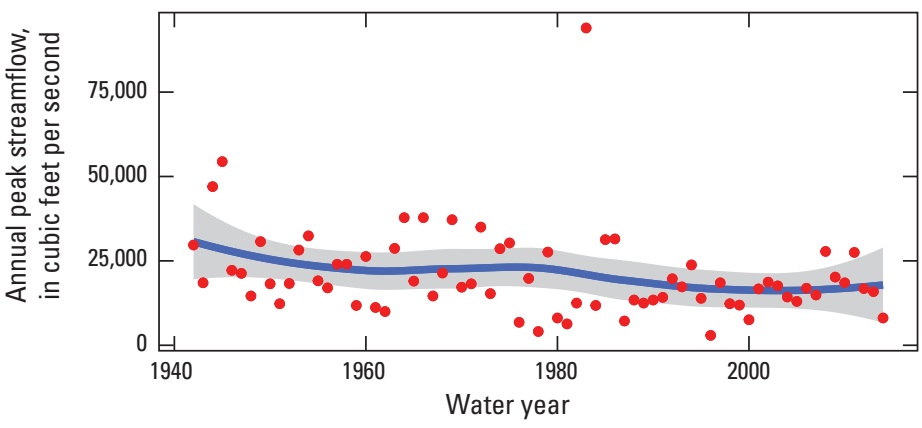

Site 2, 07069500, Spring River at Imboden, Arkansas

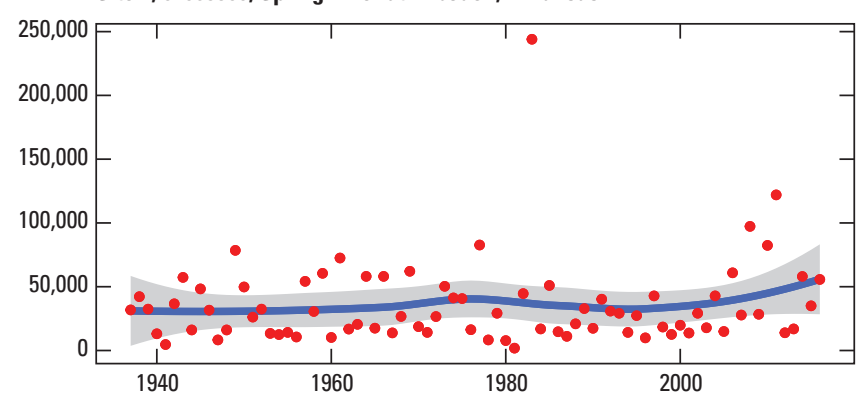

Site 4, 07074000, Strawberry River near Poughkeepsie, Arkansas

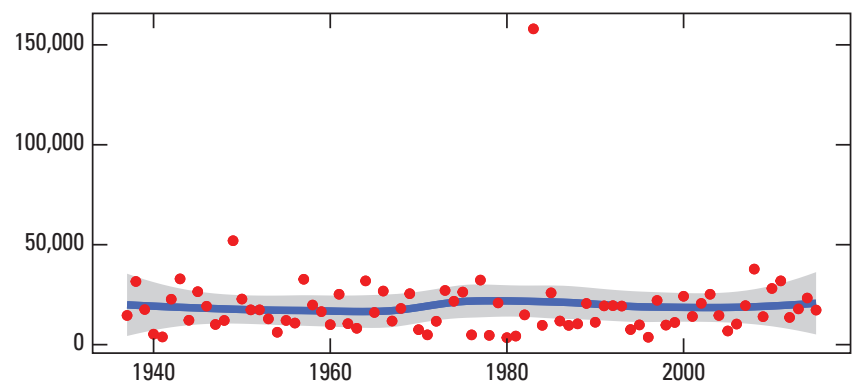

Site 6, 07194800, Illinois River at Savoy, Arkansas

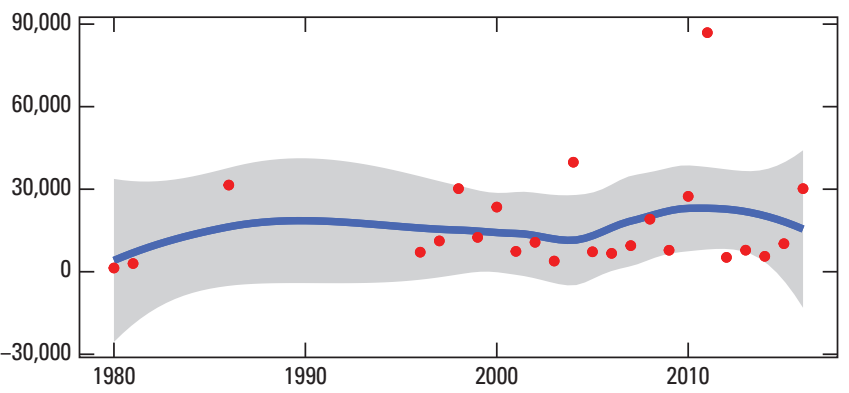

Site 8, 07260000, Dutch Creek at Waltreak, Arkansas

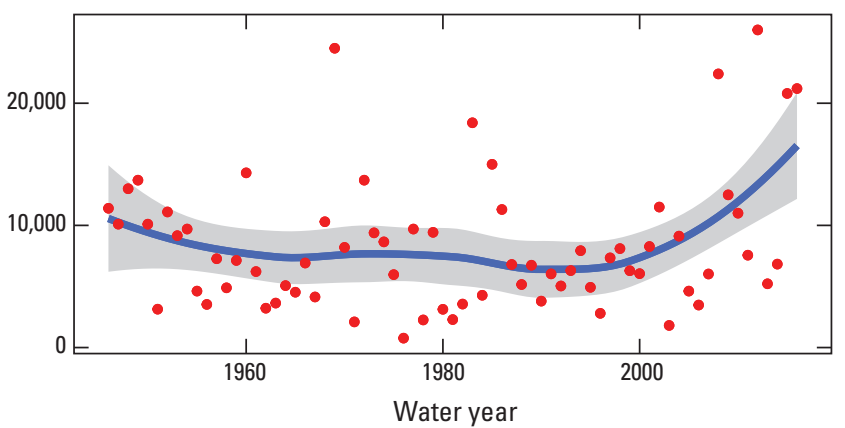

EXPLANATION

[A water year is defined as the 12-month period from October 1 through September 30 of the following year and is designated by the year in which it ends]

95-percent confidence limit

Locally estimated scatterplot smoothing trend lines

Annual peak streamflow

Figure 3. Locally estimated scatterplot smoothing trend lines of the annual peak streamflow data at the 15 selected streamgages for the full period of record. 
Site 10, 07340300, Cossatot River near Vandervoort, Arkansas

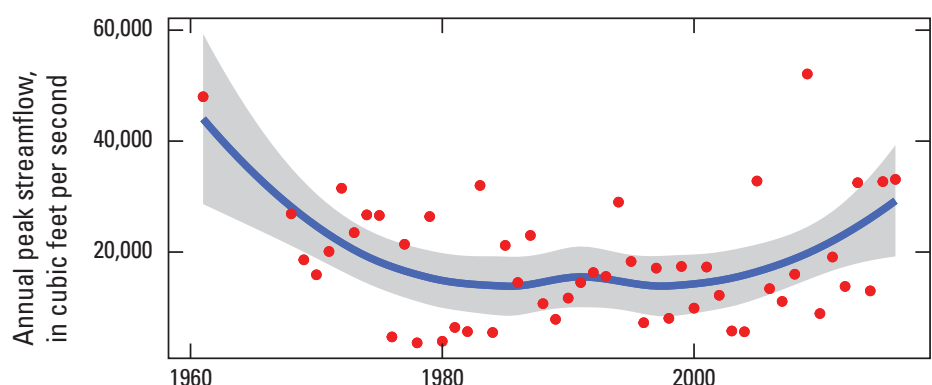

Site 12, 07362100, Smackover Creek near Smackover, Arkansas

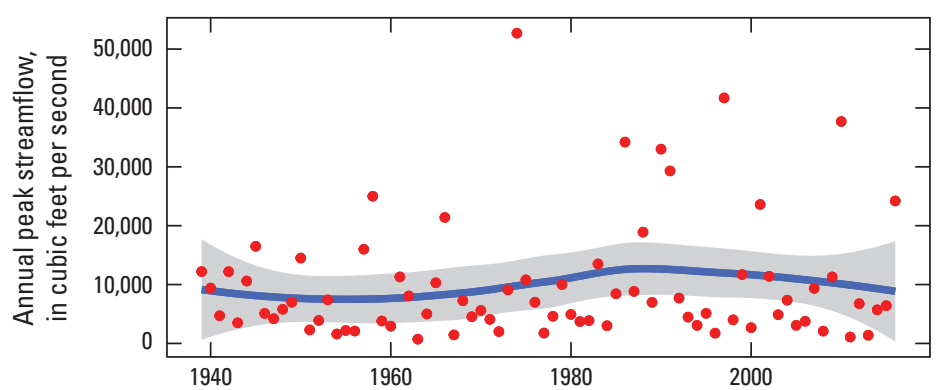

Site 14, 07364120, Bayou Bartholomew near Star City, Arkansas

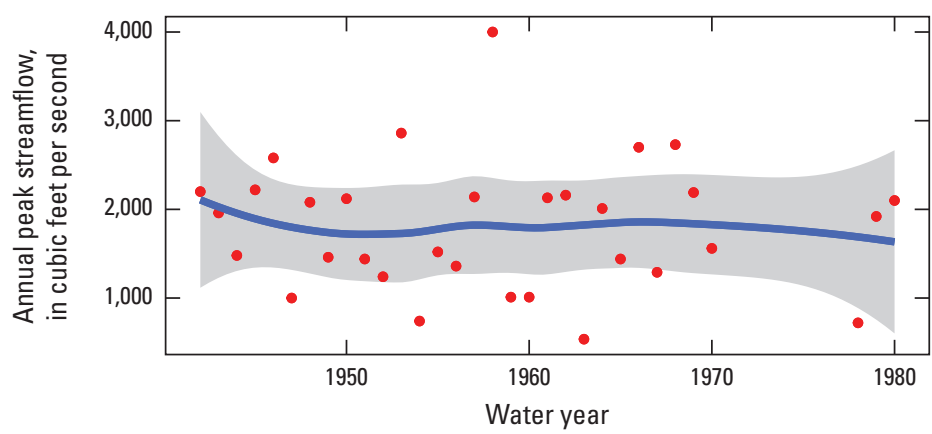

Site 11, 07361500, Antoine River at Antoine, Arkansas

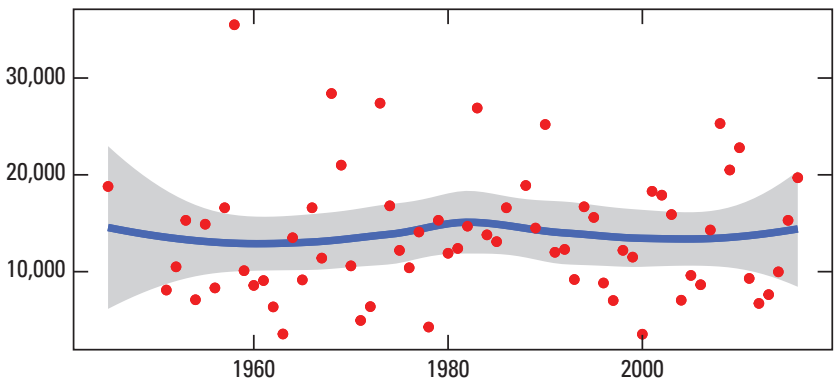

Site 13, 07363500, Saline River near Rye, Arkansas

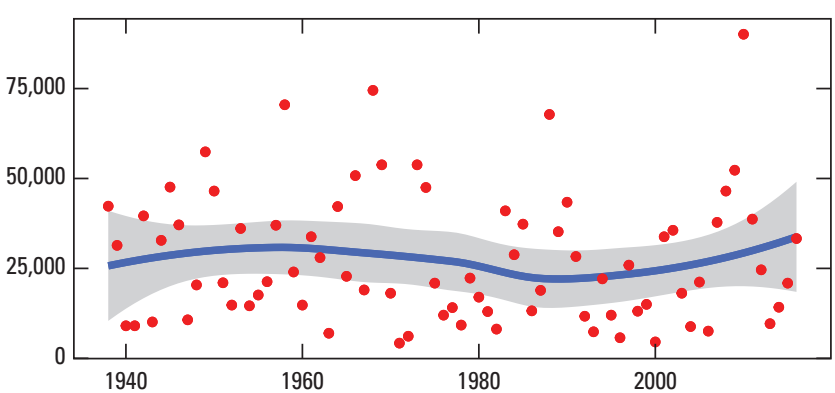

Site 15, 07369680, Bayou Macon at Eudora, Arkansas

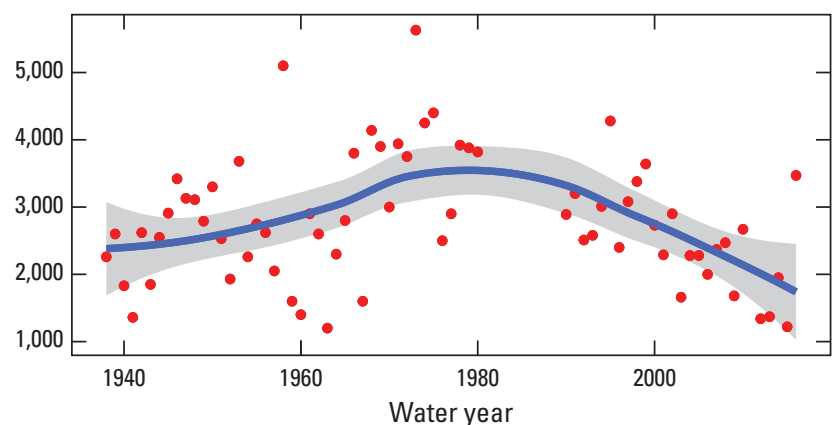

EXPLANATION

[A water year is defined as the 12-month period from 0 ctober 1 through September 30 of the following year and is designated by the year in which it ends]

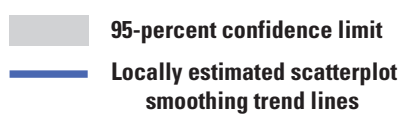

- Annual peak streamflow

Figure 3. Graphs showing ILocally estimated scatterplot smoothing trend lines of the annual peak streamflow data at the 15 selected streamgages for the full period of record.-Continued 
20-year annual peak streamflow subset of annual peak streamflow data that provided adequate number of peak streamflow data to initially estimate the initial 1-percent AEPF (table 2). Subsequently, the next 10 years of peak streamflow data were appended to this initial peak streamflow data subset, and the 1-percent AEPF was reevaluated. This process continued until the full period of record was analyzed for the 1-percent AEPF. The resulting sequential estimates of the 1-percent AEPF (table 2) were plotted with 90-percent confidence intervals and the annual peak streamflow data to document the temporal changes of the 1-percent AEPF with increasing peak streamflow record length at each streamgage location (fig. 4). The PDs of the sequential estimates from the initial 1-percent AEPF were calculated as follows:

$$
P D:\left(Q_{1 \%(N)}\right)=\frac{\left(Q_{1 \%(N)}-Q_{1 \%(I)}\right)}{Q_{1 \%(I)}} \times 100
$$

where

$P D:\left(Q_{1 \%(N)}\right) \quad$ is the percentage difference between the 1-percent AEPF from the $N$ th subset of peak streamflow data and the 1-percent $\operatorname{AEPF}\left(Q_{1 \%(I)}\right)$ from the initial subset of peak streamflow data as listed in table 2;

$Q_{1 \%(N)} \quad$ is the 1-percent AEPF calculated from the $N$ th subset of peak streamflow data as listed in table 2; and

$Q_{1 \%(l)} \quad$ is the 1-percent AEPF calculated from the initial subset of peak streamflow data as listed in table 2.

This analysis indicated a maximum increase in the 1-percent AEPF of 113 percent at site 3 (fig. 1) on Eleven Point River in northeastern Arkansas and a maximum decrease in the 1-percent AEPF of 31.9 percent at site 7 (fig. 1) on James Fork in west-central Arkansas (table 2).

\section{Arkansas Regional Regression Equations Comparison}

The RREs were published for Arkansas in 1995 (Hodge and Tasker, 1995) for estimating AEPFs at ungaged locations in Arkansas. The RREs were updated in 2016 (Wagner and others, 2016) using 20 years of additional annual peak streamflow data, improved statistical techniques, and regionalized skews. The 2016 RREs also differed from the 1995 RREs by incorporating additional or different basin and climatic characteristics that were determined using geographic information systems and available digital datasets (Wagner and others, 2016).

The RREs from Hodge and Tasker (1995) and Wagner and others (2016) were used to estimate AEPFs at the 15 selected streamgages and compare PDs between the estimates. To broaden the range of the 2016 and 1995 AEPF comparisons, AEPFs also were computed at 59 ungaged sites that

are $0-, 10-, 50-$, and 85 -percent locations along the 15 selected streams where these locations are within the Arkansas State boundary (fig. 4). The 0-percent location refers to the mouth of the stream on which the streamgage is located, and the 85-percent location refers to the distance 85 percent along the stream length, upstream from the mouth.

The PD change between AEPFs estimated from the 2016 and 1995 RREs at the 15 streamgage locations and the 59 percent locations along each of the selected streams (table 3 ) for each $\mathrm{AEPF}$ were calculated using the following equation:

$$
P D_{(\text {change })}=\frac{\left(A E P F_{(2016)}-A E P F_{(1995)}\right)}{A E P F_{(1995)}} \times 100
$$

where
\[ P D_{\text {(change) }} \]

is the percentage difference change, which represents the percentage change between the 2016 AEPF estimates and the 1995 AEPF estimates;

$A E P F_{(2016)} \quad$ is the AEPF calculated from the $2016 \mathrm{RRE}$ (Wagner and others, 2016), in cubic feet per second; and

$A E P F_{(1995)} \quad$ is the AEPF calculated from the $1995 \mathrm{RRE}$

(Hodge and Tasker, 1995), in cubic feet per second.

PD change is positive when the 2016 AEPF estimates exceed the 1995 AEPF estimates. Conversely, PD change is negative when the 2016 AEPF estimates are less than the 1995 AEPF estimates. This analysis is based on a small sample size of 74 selected streamflow locations in Arkansas and, therefore, only reflects the actual PD changes that may exist between the 2016 and 1995 AEPFs. Also, the 2016 and 1995 AEPF standard error of estimate, in percent, far exceeds the PDs determined in this comparative analysis. Regardless, the average PD change between AEPFs at the 74 streamflow locations was calculated and plotted with the associated RI; the resulting graph shows a near linear relation between the average PD change and log base 10 transformed RI (fig. 5). The average PDs between the 2016 and 1995 AEPFs indicate the 2016 AEPF estimates were higher than the 1995 AEPFs by an average of 3.52, 5.10, 8.59, and 13.31 percent for the 4-, 2-, 1-, and 0.2-percent AEPFs (25-, 50-, 100-, and 500-year RI floods), respectively. The average PDs between the 2016 and 1995 AEPFs were similar for the 20-percent and 10-percent AEPFs (5-year and 10-year RI floods) and were 0.31 percent lower and 0.41 percent higher, respectively. For the 50 -percent AEPF (2-year RI flood) estimate, the 2016 AEPFs were less than the 1995 AEPFs by an average PD of 2.53 percent (fig. 5).

The boxplots in figure 6 show the range of PDs from the 2016 and 1995 AEPFs and the differences between flood regions (fig. 2). The maximum PD of 112 percent was in region $\mathrm{C}$ at the 85-percent location at South Fork of Little Red River at Clinton (USGS station 07075300, site 5 in fig. 1 and sites 20-24 in fig. 2) for the 0.2-percent AEPF (500-year 
Table 2. The 15 selected streamgages used in this study and the percentage differences from the initial 1-percent annual exceedance probability flood estimate for each subsequent 1-percent annual exceedance probability flood reevaluation.

[USGS, U.S. Geological Survey; \%, percent; AEPF, annual exceedance probability flood; PD, percentage difference]

\begin{tabular}{|c|c|c|c|c|}
\hline $\begin{array}{c}\text { Site } \\
\text { number } \\
\text { (fig. 1) }\end{array}$ & $\begin{array}{c}\text { USGS } \\
\text { station } \\
\text { number (fig. 1) }\end{array}$ & $\begin{array}{l}\text { Period of } \\
\text { record }\end{array}$ & $1 \%$ AEPF & $\begin{array}{l}\text { PD from } \\
1 \% A E P F, \\
\text { in percent }\end{array}$ \\
\hline \multirow[t]{5}{*}{1} & 07060710 & $1966-1976$ & 26,200 & 0.00 \\
\hline & & 1966-1986 & 38,140 & 45.57 \\
\hline & & 1966-1996 & 34,010 & 29.81 \\
\hline & & 1966-2006 & 31,470 & 20.11 \\
\hline & & 1966-2016 & 35,950 & 37.21 \\
\hline \multirow[t]{8}{*}{2} & ${ }^{\mathrm{a}} 07069500$ & 1915-1946 & 117,300 & 0.00 \\
\hline & & 1915-1956 & 134,800 & 14.92 \\
\hline & & 1915-1966 & 144,900 & 23.53 \\
\hline & & 1915-1976 & 118,900 & 1.36 \\
\hline & & 1915-1986 & 163,300 & 39.22 \\
\hline & & 1915-1996 & 149,800 & 27.71 \\
\hline & & 1915-2006 & 142,000 & 21.06 \\
\hline & & 1915-2016 & 154,500 & 31.71 \\
\hline \multirow[t]{8}{*}{3} & 07072000 & 1930-1946 & 40,440 & 0.00 \\
\hline & & 1930-1956 & 42,030 & 3.93 \\
\hline & & 1930-1966 & 55,050 & 36.13 \\
\hline & & 1930-1976 & 52,000 & 28.59 \\
\hline & & 1930-1986 & 78,340 & 93.72 \\
\hline & & 1930-1996 & 73,650 & 82.12 \\
\hline & & 1930-2006 & 75,270 & 86.13 \\
\hline & & 1930-2016 & 86,320 & ${ }^{b} 113.45$ \\
\hline \multirow[t]{7}{*}{4} & 07074000 & $1937-1955$ & 61,730 & 0.00 \\
\hline & & 1937-1965 & 56,030 & -9.23 \\
\hline & & 1937-1975 & 54,200 & -12.20 \\
\hline & & 1937-1985 & 84,820 & 37.40 \\
\hline & & 1937-1995 & 75,890 & 22.94 \\
\hline & & $1937-2005$ & 71,260 & 15.44 \\
\hline & & $1937-2015$ & 68,720 & 11.32 \\
\hline \multirow[t]{5}{*}{5} & 07075300 & $1962-1976$ & 51,530 & 0.00 \\
\hline & & 1962-1986 & 64,310 & 24.80 \\
\hline & & 1962-1996 & 55,220 & 7.16 \\
\hline & & $1962-2006$ & 48,690 & -5.51 \\
\hline & & $1962-2016$ & 46,680 & -9.41 \\
\hline \multirow[t]{2}{*}{6} & 07194800 & 1980-2006 & 78,230 & 0.00 \\
\hline & & 1980-2016 & 90,890 & 16.18 \\
\hline \multirow[t]{5}{*}{7} & 07249400 & 1958-1976 & 39,690 & 0.00 \\
\hline & & 1958-1986 & 31,520 & -20.58 \\
\hline & & 1958-1996 & 27,040 & $c_{-}-31.87$ \\
\hline & & 1958-2006 & 27,490 & -30.74 \\
\hline & & 1958-2016 & 29,270 & -26.25 \\
\hline \multirow[t]{7}{*}{8} & ${ }^{\mathrm{a}} 07260000$ & 1927-1956 & 15,840 & 0.00 \\
\hline & & 1927-1966 & 19,710 & 24.43 \\
\hline & & 1927-1976 & 23,160 & 46.21 \\
\hline & & 1927-1986 & 24,910 & 57.26 \\
\hline & & 1927-1996 & 22,860 & 44.31 \\
\hline & & 1927-2006 & 21,790 & 37.56 \\
\hline & & 1927-2016 & 26,320 & 66.16 \\
\hline
\end{tabular}

\begin{tabular}{|c|c|c|c|c|}
\hline $\begin{array}{c}\text { Site } \\
\text { number } \\
\text { (fig. 1) }\end{array}$ & $\begin{array}{c}\text { USGS } \\
\text { station } \\
\text { number (fig. 1) }\end{array}$ & $\begin{array}{l}\text { Period of } \\
\text { record }\end{array}$ & $1 \%$ AEPF & $\begin{array}{c}\text { PD from } \\
1 \% \text { AEPF, } \\
\text { in percent }\end{array}$ \\
\hline \multirow[t]{7}{*}{9} & 07263000 & $1942-1954$ & 66,420 & 0.00 \\
\hline & & 1942-1964 & 60,540 & -8.85 \\
\hline & & $1942-1974$ & 58,220 & -12.35 \\
\hline & & 1942-1984 & 73,850 & 11.19 \\
\hline & & 1942-1994 & 68,890 & 3.72 \\
\hline & & 1942-2004 & 65,550 & -1.31 \\
\hline & & $1942-2014$ & 61,770 & -7.00 \\
\hline \multirow[t]{5}{*}{10} & ${ }^{\mathrm{a}} 07340300$ & 1961-1976 & 69,390 & 0.00 \\
\hline & & 1961-1986 & 53,290 & -23.20 \\
\hline & & 1961-1996 & 54,570 & -21.36 \\
\hline & & $1961-2006$ & 52,080 & -24.95 \\
\hline & & $1961-2016$ & 59,660 & -14.02 \\
\hline \multirow[t]{6}{*}{11} & ${ }^{\mathrm{a}} 07361500$ & 1905-1966 & 37,850 & 0.00 \\
\hline & & 1905-1976 & 39,710 & 4.91 \\
\hline & & 1905-1986 & 38,300 & 1.19 \\
\hline & & 1905-1996 & 36,930 & -2.43 \\
\hline & & 1905-2006 & 35,280 & -5.36 \\
\hline & & 1905-2016 & 36,000 & -4.86 \\
\hline \multirow[t]{7}{*}{12} & 07362100 & 1939-1956 & 26,990 & 0.00 \\
\hline & & 1939-1966 & 36,810 & 36.38 \\
\hline & & 1939-1976 & 42,990 & 59.28 \\
\hline & & 1939-1986 & 43,710 & 61.95 \\
\hline & & 1939-1996 & 48,230 & 78.70 \\
\hline & & 1939-2006 & 51,250 & 89.89 \\
\hline & & 1939-2016 & 53,860 & 99.56 \\
\hline \multirow[t]{8}{*}{13} & ${ }^{\mathrm{a}} 07363500$ & 1927-1946 & 112,800 & 0.00 \\
\hline & & 1927-1956 & 95,220 & -15.59 \\
\hline & & 1927-1966 & 97,060 & -13.95 \\
\hline & & 1927-1976 & 108,200 & -4.08 \\
\hline & & 1927-1986 & 101,200 & -10.28 \\
\hline & & 1927-1996 & 101,900 & -9.66 \\
\hline & & 1927-2006 & 97,950 & -13.16 \\
\hline & & $1927-2016$ & 101,800 & -9.75 \\
\hline \multirow[t]{3}{*}{14} & 07364120 & $1927-1960$ & 4,297 & 0.00 \\
\hline & & $1927-1970$ & 4,088 & -4.86 \\
\hline & & $1927-1980$ & 4,155 & -3.30 \\
\hline \multirow[t]{7}{*}{15} & ${ }^{\mathrm{a}} 07369680$ & $1932-1956$ & 4,287 & 0.00 \\
\hline & & 1932-1966 & 4,920 & 14.77 \\
\hline & & 1932-1976 & 5,803 & 35.36 \\
\hline & & 1932-1986 & 5,810 & 35.53 \\
\hline & & 1932-1996 & 5,607 & 30.79 \\
\hline & & $1932-2006$ & 5,427 & 26.59 \\
\hline & & $1932-2016$ & 5,446 & 27.04 \\
\hline
\end{tabular}

aPeriod of record includes historic peak streamflows.

${ }^{b}$ Value is the maximum increase in the 1-percent AEPF.

${ }^{c}$ Value is the maximum decrease in the 1-percent AEPF. 

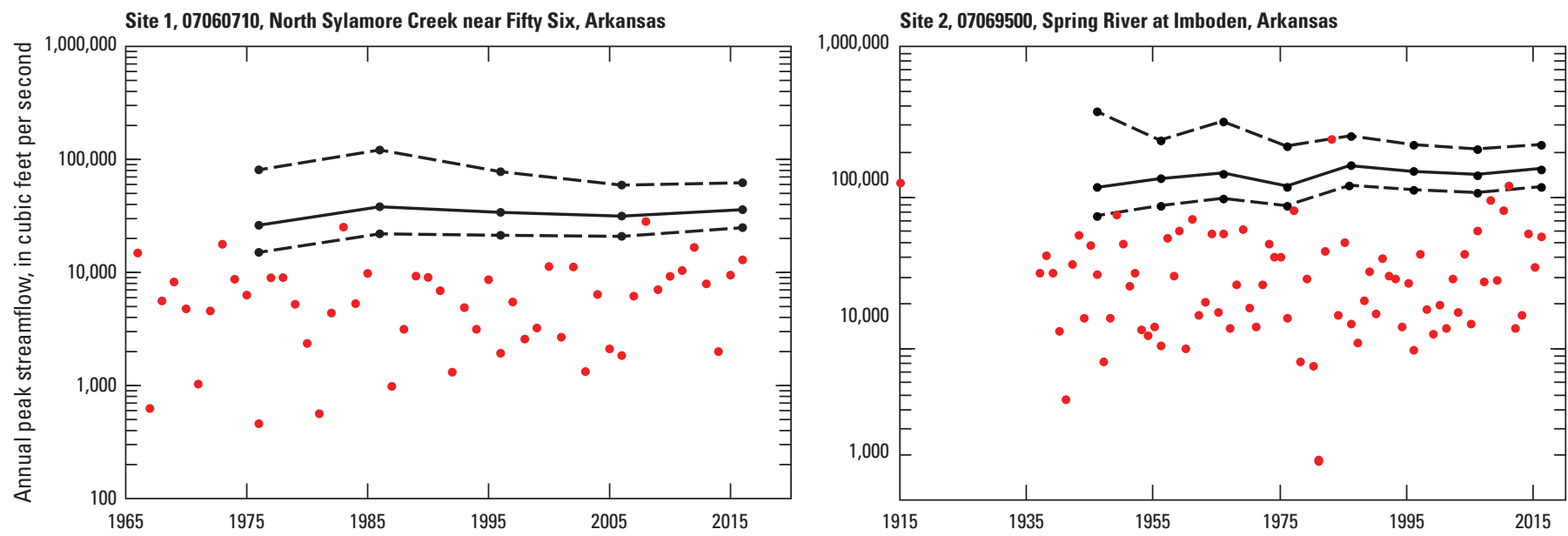

Site 3, 07072000, Eleven Point River near Ravenden Springs, Arkansas

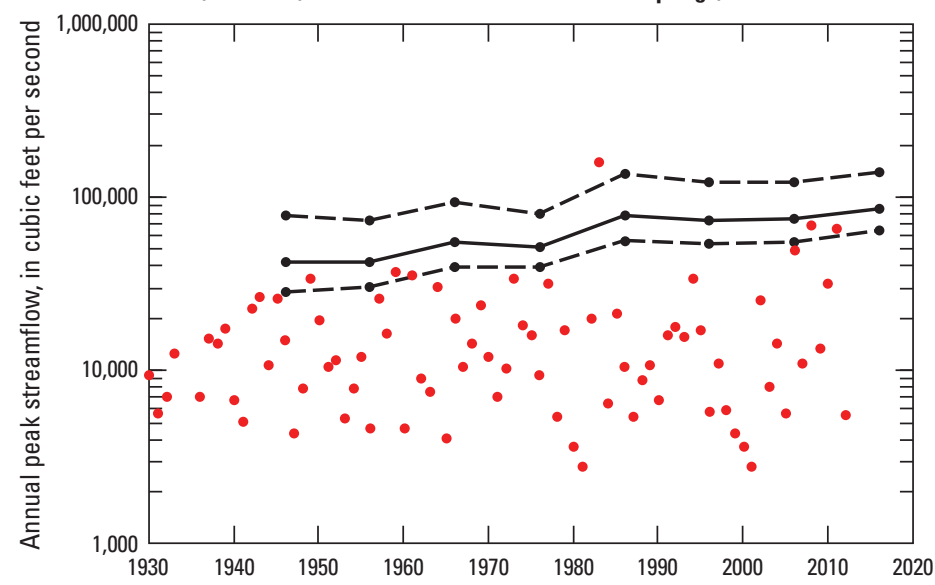

Site 4, 07074000, Strawberry River near Poughkeepsie, Arkansas
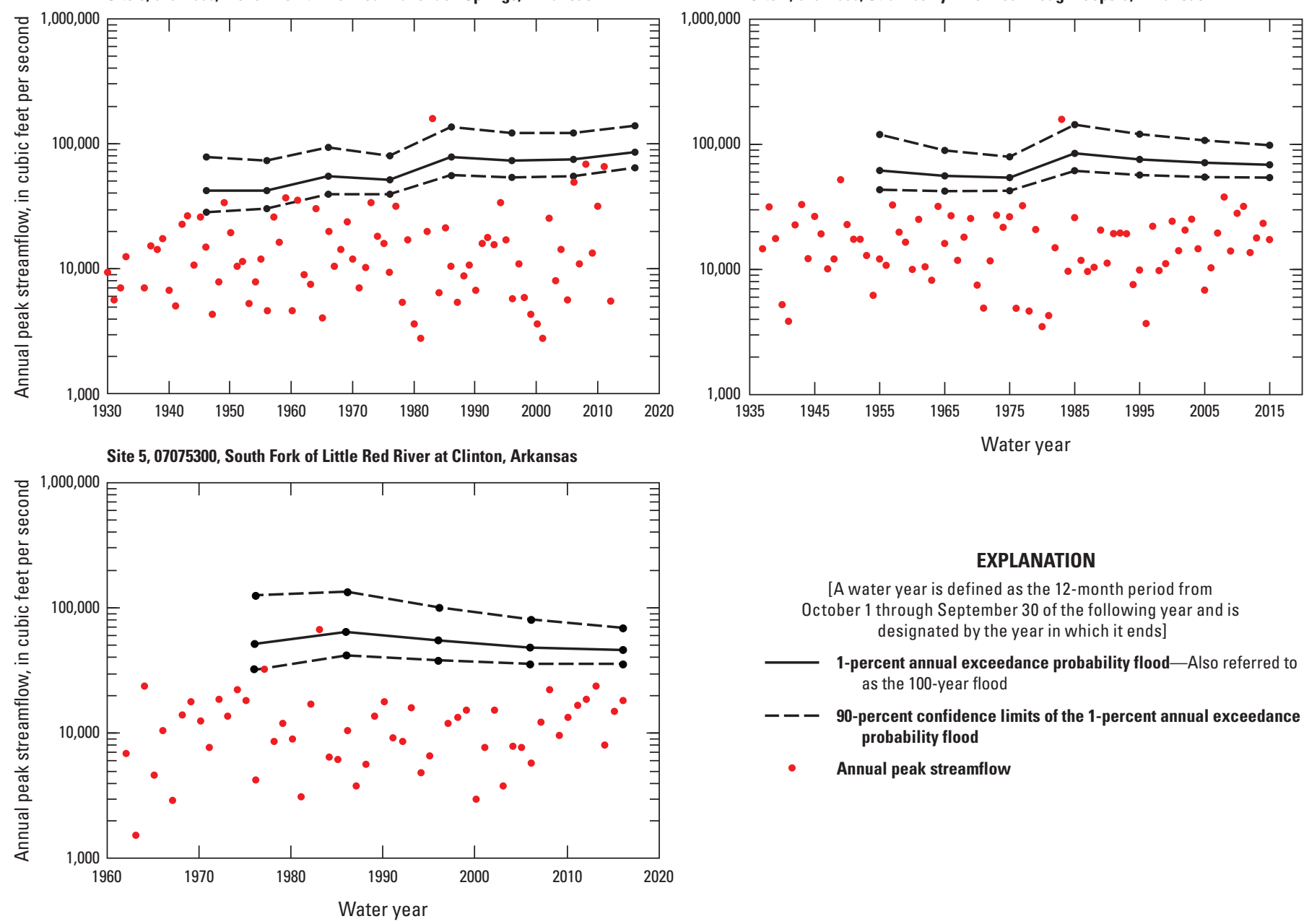

\section{EXPLANATION}

[A water year is defined as the 12-month period from October 1 through September 30 of the following year and is designated by the year in which it ends]

1-percent annual exceedance probability flood-Also referred to as the 100-year flood

90-percent confidence limits of the 1-percent annual exceedance probability flood

- Annual peak streamflow

Figure 4. The 1-percent annual exceedance probability flood trend for the 15 selected streamgages plotted with the annual peak for the full period of record. 

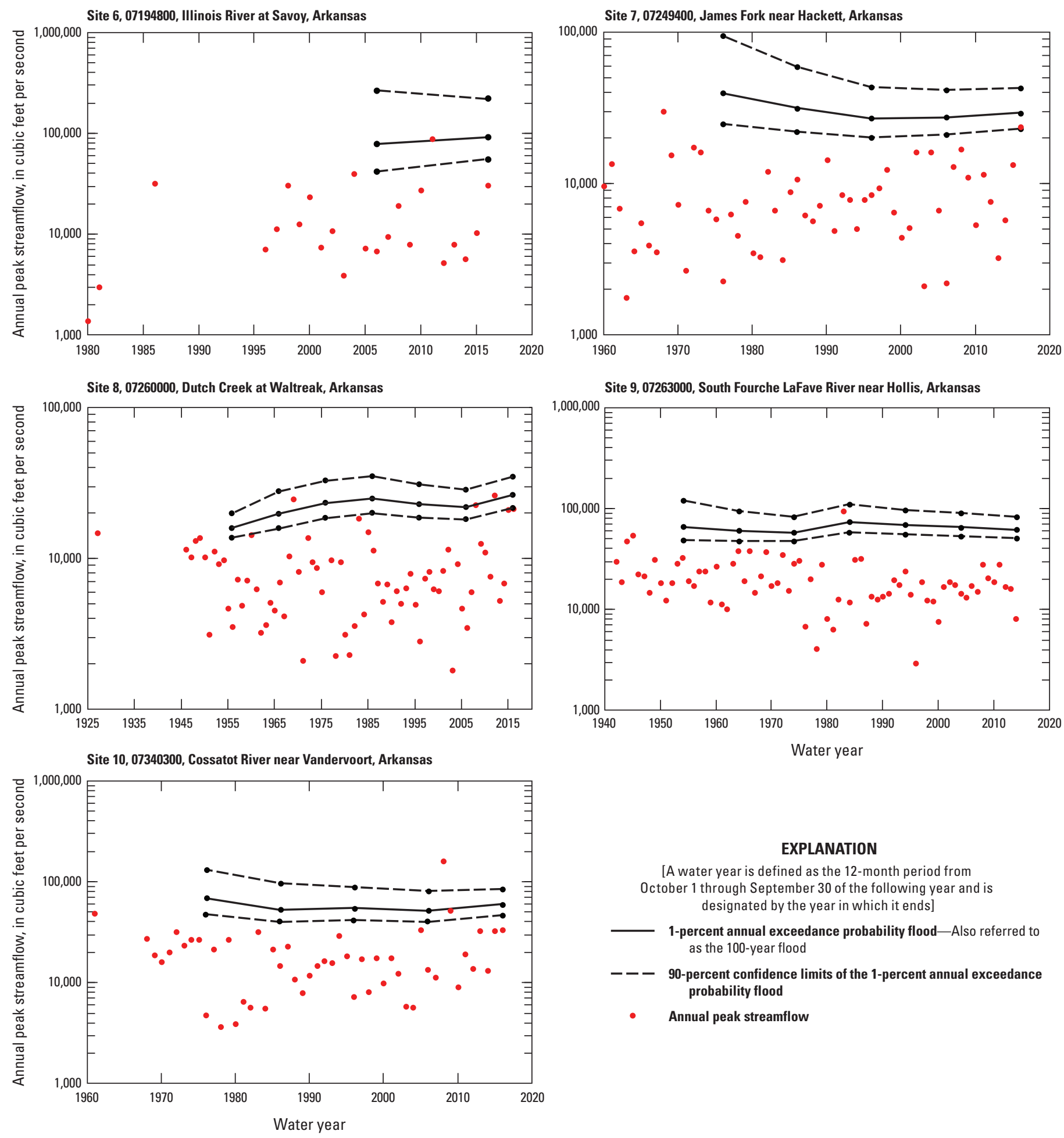

\section{EXPLANATION}

[A water year is defined as the 12-month period from October 1 through September 30 of the following year and is designated by the year in which it ends]

1-percent annual exceedance probability flood-Also referred to as the 100 -year flood

90-percent confidence limits of the 1-percent annual exceedance probability flood

- Annual peak streamflow

Figure 4. The 1-percent annual exceedance probability flood trend for the 15 selected streamgages plotted with the annual peak for the full period of record.-Continued 
Site 11, 07361500, Antoine River at Antoine, Arkansas

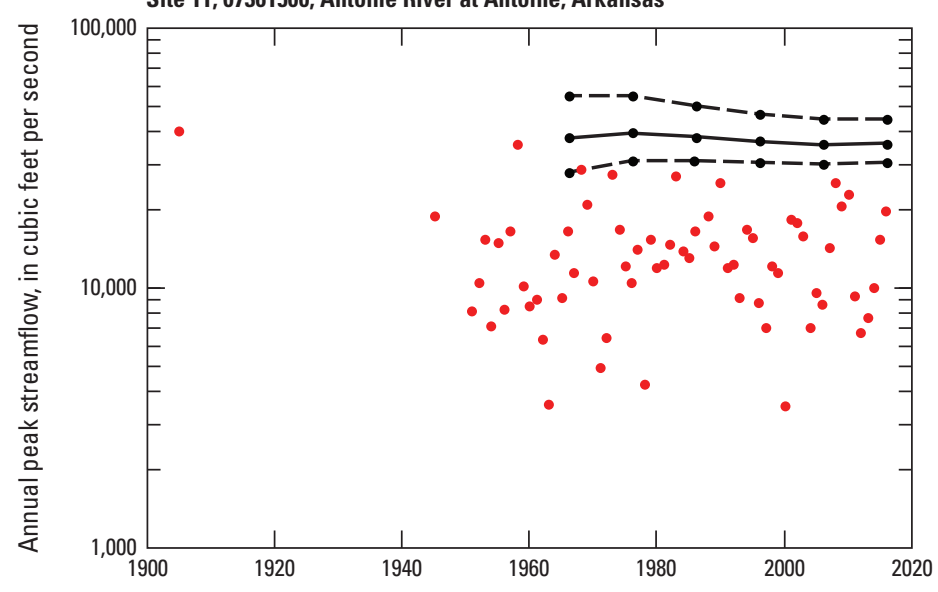

Site 13, 07363500, Saline River near Rye, Arkansas

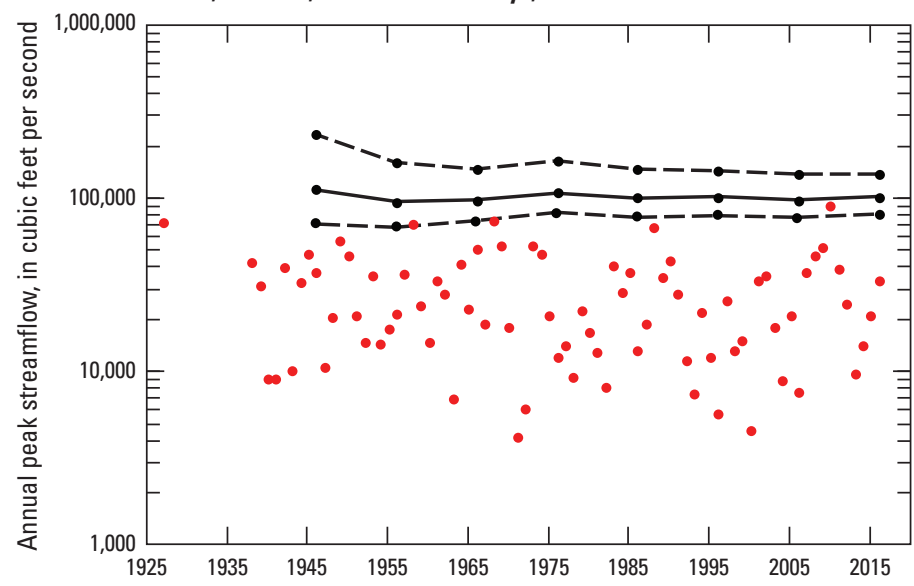

Site 15, 07369680, Bayou Macon at Eudora, Arkansas

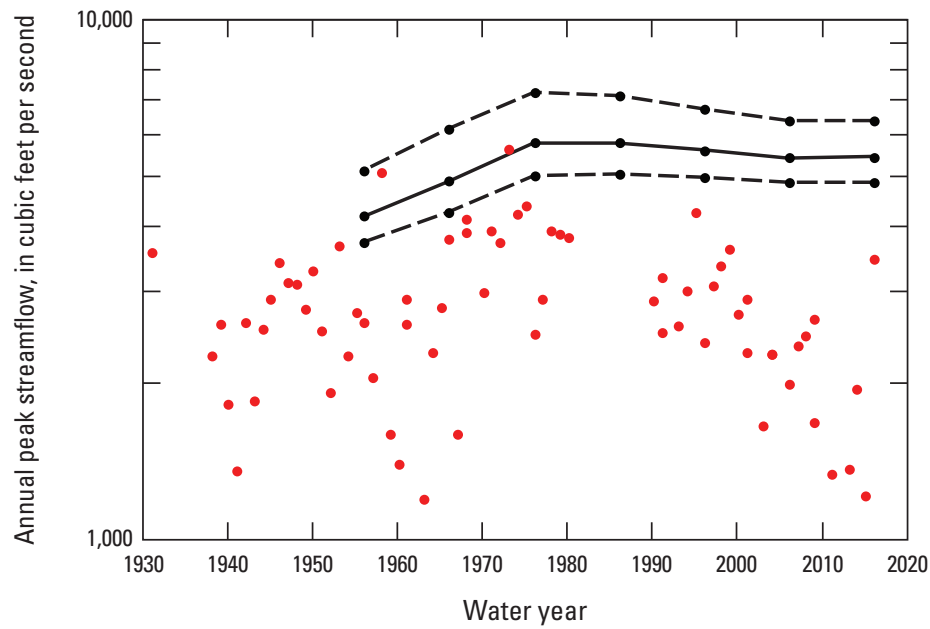

Site 12, 07362100, Smackover Creek near Smackover, Arkansas

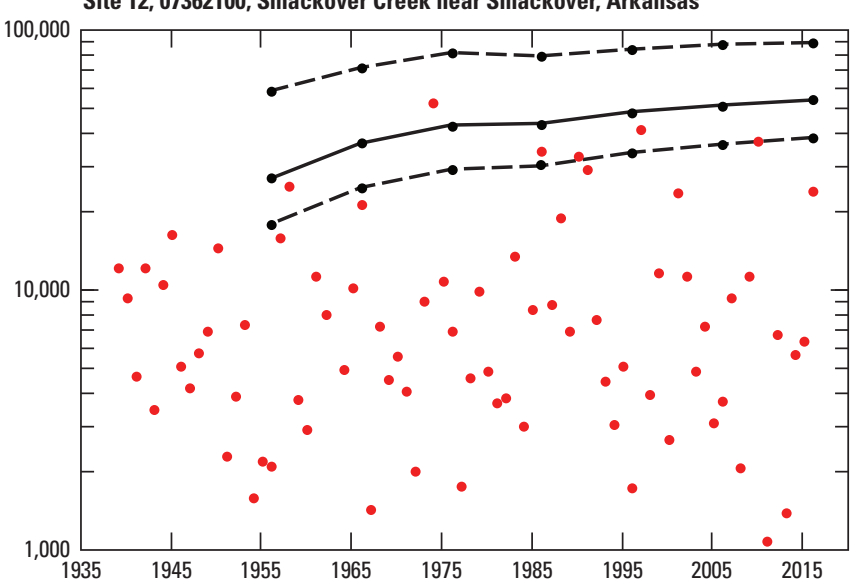

Site 14, 07364120, Bayou Bartholomew near Star City, Arkansas

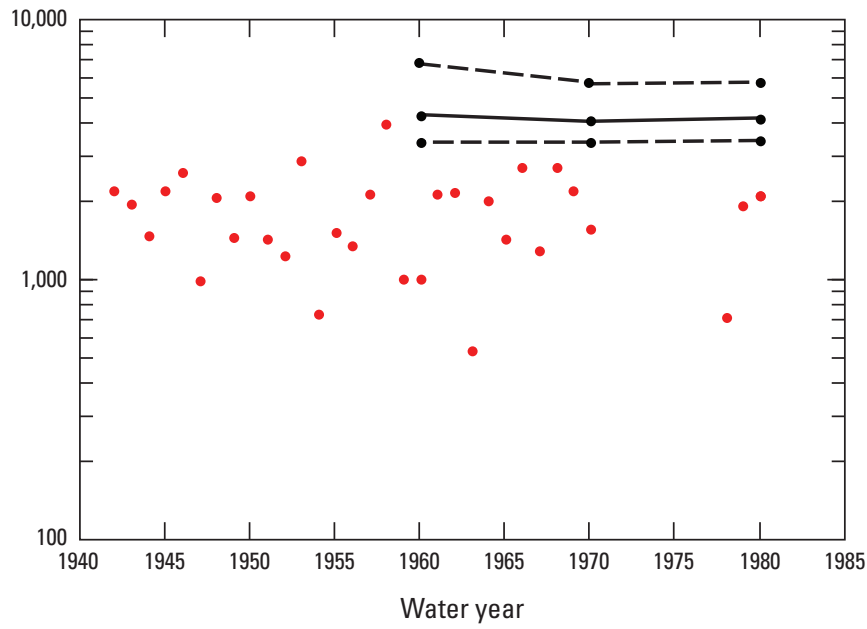

EXPLANATION

[A water year is defined as the 12-month period from October 1 through September 30 of the following year and is designated by the year in which it ends]

1-percent annual exceedance probability flood-Also referred to as the 100-year flood

90-percent confidence limits of the 1-percent annual exceedance probability flood

- Annual peak streamflow

Figure 4. The 1-percent annual exceedance probability flood trend for the 15 selected streamgages plotted with the annual peak for the full period of record.-Continued 


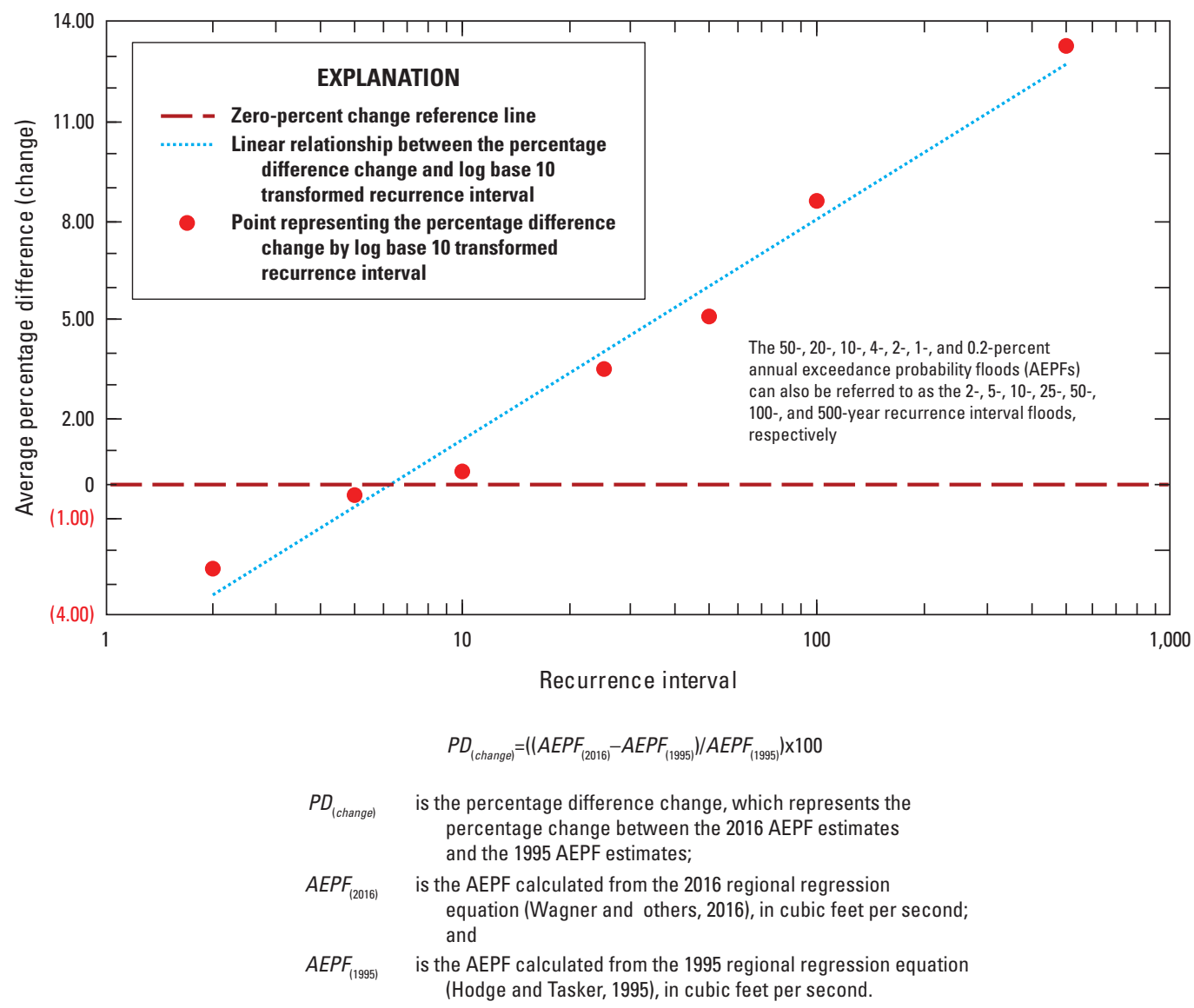

Figure 5. Relation between the log base 10 transformed recurrence interval and the average percentage difference change between the 2016 and 1995 annual exceedance probability flood estimates for the 74 streamflow locations representing 15 streamgages and the $0-, 10-, 50-$, and 85-percent locations along the stream, terminating at the Arkansas border. 
Table 3. The percentage difference between the 2016 and 1995 annual exceedance probability floods for the 74 selected streamflow locations, which include the 15 selected streamgage locations and the $0-, 10-, 50-$, and 85 -percent locations along each of the selected streams, terminating at the Arkansas border, when applicable.

[A positive percentage difference change value denotes the 2016 annual exceedance probability flood is greater than the 1995 annual exceedance probability flood; therefore, a negative percentage difference change value (denoted in red with parentheses) denotes the 2016 annual exceedance probability flood is less than the 1995 annual exceedance probability flood; USGS, U.S. Geological Survey]

\begin{tabular}{|c|c|c|c|c|c|c|c|c|c|c|c|}
\hline \multirow{4}{*}{$\begin{array}{c}\text { Site } \\
\text { number } \\
\text { (fig. 5) }\end{array}$} & \multirow{4}{*}{$\begin{array}{l}\text { Percent } \\
\text { location }\end{array}$} & \multirow{4}{*}{$\begin{array}{l}\text { Flood } \\
\text { region } \\
\text { (fig. 2) }\end{array}$} & \multirow{4}{*}{ Latitude } & \multirow{4}{*}{ Longitude } & \multicolumn{7}{|c|}{ Annual exceedance probability, in percent } \\
\hline & & & & & 50 & 20 & 10 & 4 & 2 & 1 & 0.2 \\
\hline & & & & & \multicolumn{7}{|c|}{ Recurrence interval, in years } \\
\hline & & & & & \multicolumn{7}{|c|}{ Percentage differences in annual exceedance probability flood, in percent } \\
\hline \multicolumn{12}{|c|}{ USGS station 07060710} \\
\hline 2 & $0 \%$ & $\mathrm{C}$ & 35.9408 & -92.120 & 3.89 & 11.12 & 1.29 & 3.88 & 4.90 & 6.81 & 9.89 \\
\hline 3 & $10 \%$ & $\mathrm{C}$ & 35.964 & -92.152 & 4.30 & 11.52 & 9.40 & 13.77 & 16.67 & 19.75 & 25.88 \\
\hline 4 & $50 \%$ & $\mathrm{C}$ & 36.010 & -92.244 & 3.70 & 10.68 & 32.60 & 46.51 & 55.54 & 65.22 & 83.59 \\
\hline 5 & $85 \%$ & $\mathrm{C}$ & 36.063 & -92.328 & $(3.66)$ & 5.81 & 18.12 & 26.90 & 31.95 & 38.40 & 48.52 \\
\hline \multicolumn{12}{|c|}{ USGS station 07069500} \\
\hline 9 & $50 \%$ & $\mathrm{C}$ & 36.365 & -91.515 & $(22.64)$ & (18.16) & (11.34) & $(4.09)$ & $(0.08)$ & 4.67 & 14.14 \\
\hline 10 & Border & $\mathrm{C}$ & 36.497 & -91.528 & $(25.02)$ & $(21.30)$ & $(23.60)$ & $(20.22)$ & $(18.46)$ & $(15.93)$ & $(11.29)$ \\
\hline \multicolumn{12}{|c|}{ USGS station 07072000} \\
\hline 11 & At site & $\mathrm{C}$ & 36.347 & -91.114 & $(18.56)$ & $(13.55)$ & $(17.71)$ & $(13.77)$ & $(12.41)$ & $(9.82)$ & $(5.03)$ \\
\hline 12 & $0 \%$ & $\mathrm{C}$ & 36.152 & -91.083 & (18.07) & (13.18) & $(23.64)$ & (21.95) & $(21.78)$ & $(20.91)$ & $(18.23)$ \\
\hline 13 & $10 \%$ & $\mathrm{C}$ & 36.289 & -91.096 & $(18.10)$ & $(13.27)$ & (19.58) & (17.04) & (15.84) & (13.49) & (9.71) \\
\hline 14 & Border & $\mathrm{C}$ & 36.496 & -91.172 & (18.12) & $(13.02)$ & (11.04) & $(5.27)$ & $(2.27)$ & 1.24 & 9.55 \\
\hline \multicolumn{12}{|c|}{ USGS station 07074000} \\
\hline 20 & At site & $\mathrm{C}$ & 35.587 & -92.452 & 20.44 & 32.95 & 21.42 & 25.10 & 26.98 & 30.72 & 36.41 \\
\hline 21 & $0 \%$ & $\mathrm{C}$ & 35.590 & -92.448 & 20.03 & 32.07 & 20.15 & 23.73 & 25.55 & 28.84 & 34.14 \\
\hline 22 & $10 \%$ & $\mathrm{C}$ & 35.582 & -92.493 & 20.57 & 33.09 & 26.98 & 32.74 & 36.08 & 40.84 & 48.71 \\
\hline 23 & $50 \%$ & $\mathrm{C}$ & 35.577 & -92.639 & 23.17 & 35.49 & 42.52 & 52.60 & 58.96 & 66.38 & 80.14 \\
\hline 24 & $85 \%$ & $\mathrm{C}$ & 35.610 & -92.764 & 23.30 & 34.45 & 55.41 & 70.57 & 80.39 & 91.43 & 112.07 \\
\hline \multicolumn{12}{|c|}{ USGS station 07194800} \\
\hline 25 & At site & A & 36.103 & -94.344 & (3.67) & 4.03 & 9.79 & 18.39 & 20.58 & 30.17 & 40.96 \\
\hline 26 & $0 \%$ & A & 36.102 & -94.549 & (4.74) & 1.37 & 6.35 & 13.96 & 14.96 & 24.27 & 34.54 \\
\hline 27 & $10 \%$ & A & 36.133 & -94.503 & (4.87) & 1.22 & 6.22 & 13.73 & 14.64 & 24.04 & 33.87 \\
\hline 28 & $50 \%$ & A & 36.079 & -94.342 & $(4.47)$ & 3.25 & 8.84 & 17.18 & 19.28 & 28.85 & 39.19 \\
\hline 29 & $85 \%$ & A & 35.928 & -94.267 & (4.19) & 8.52 & 16.18 & 27.65 & 32.87 & 45.49 & 58.08 \\
\hline
\end{tabular}


Table 3. The percentage difference between the 2016 and 1995 annual exceedance probability floods for the 74 selected streamflow locations, which include the 15 selected streamgage locations and the $0-, 10-, 50-$, and 85 -percent locations along each of the selected streams, terminating at the Arkansas border, when applicable.-Continued

[A positive percentage difference change value denotes the 2016 annual exceedance probability flood is greater than the 1995 annual exceedance probability flood; therefore, a negative percentage difference change value (denoted in red with parentheses) denotes the 2016 annual exceedance probability flood is less than the 1995 annual exceedance probability flood; USGS, U.S. Geological Survey]

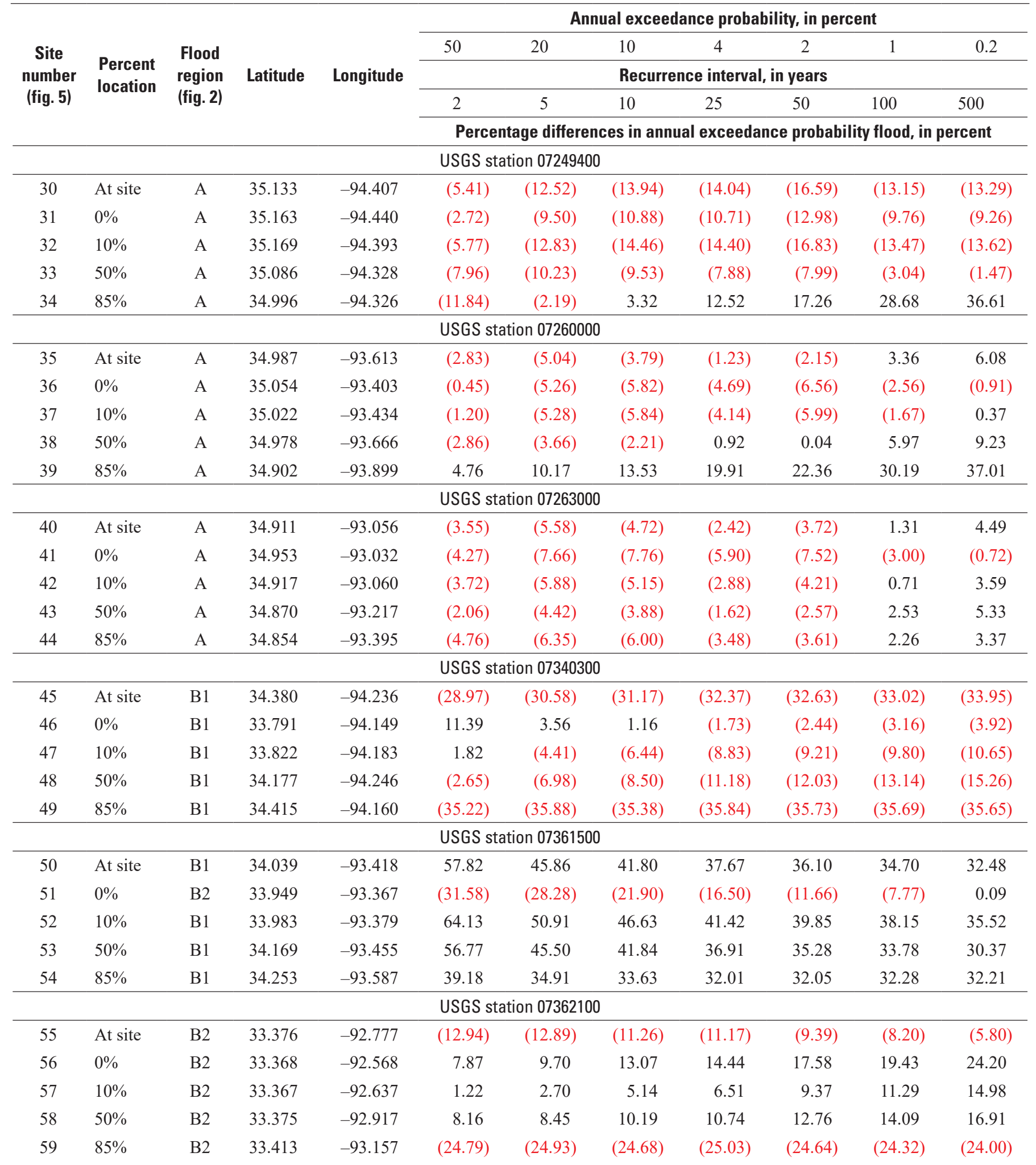


Table 3. The percentage difference between the 2016 and 1995 annual exceedance probability floods for the 74 selected streamflow locations, which include the 15 selected streamgage locations and the $0-, 10-, 50-$, and 85 -percent locations along each of the selected streams, terminating at the Arkansas border, when applicable.-Continued

[A positive percentage difference change value denotes the 2016 annual exceedance probability flood is greater than the 1995 annual exceedance probability flood; therefore, a negative percentage difference change value (denoted in red with parentheses) denotes the 2016 annual exceedance probability flood is less than the 1995 annual exceedance probability flood; USGS, U.S. Geological Survey]

\begin{tabular}{|c|c|c|c|c|c|c|c|c|c|c|c|}
\hline \multirow{4}{*}{$\begin{array}{c}\text { Site } \\
\text { number } \\
\text { (fig. 5) }\end{array}$} & \multirow{4}{*}{$\begin{array}{l}\text { Percent } \\
\text { location }\end{array}$} & \multirow{4}{*}{$\begin{array}{l}\text { Flood } \\
\text { region } \\
\text { (fig. 2) }\end{array}$} & \multirow{4}{*}{ Latitude } & \multirow{4}{*}{ Longitude } & \multicolumn{7}{|c|}{ Annual exceedance probability, in percent } \\
\hline & & & & & 50 & 20 & 10 & 4 & 2 & 1 & 0.2 \\
\hline & & & & & \multicolumn{7}{|c|}{ Recurrence interval, in years } \\
\hline & & & & & \multicolumn{7}{|c|}{ Percentage differences in annual exceedance probability flood, in percent } \\
\hline \multicolumn{12}{|c|}{ USGS station 07363500} \\
\hline 61 & $0 \%$ & B2 & 33.163 & -92.137 & $(24.18)$ & $(13.92)$ & $(6.78)$ & $(0.99)$ & 4.59 & 8.60 & 16.39 \\
\hline 62 & $10 \%$ & B2 & 33.163 & -92.137 & $(23.43)$ & $(14.05)$ & $(7.23)$ & (1.99) & 3.25 & 6.82 & 14.44 \\
\hline 63 & $50 \%$ & B2 & 34.124 & -92.426 & (33.16) & $(26.22)$ & $(21.40)$ & $(17.59)$ & $(13.50)$ & $(10.48)$ & (4.14) \\
\hline 64 & $85 \%$ & B1 & 34.648 & -92.756 & 3.32 & $(1.81)$ & $(2.76)$ & $(4.41)$ & $(4.20)$ & $(4.16)$ & $(3.55)$ \\
\hline \multicolumn{12}{|c|}{ USGS station 07364120} \\
\hline 68 & $50 \%$ & $\mathrm{D}$ & 33.27 & -91.554 & -0.39 & 2.56 & 5.16 & 7.71 & 9.71 & 11.27 & 15.88 \\
\hline 69 & $85 \%$ & $\mathrm{D}$ & 34.079 & -91.919 & 19.22 & 24.90 & 28.85 & 33.16 & 36.44 & 39.38 & 46.19 \\
\hline \multicolumn{12}{|c|}{ USGS station 07369680} \\
\hline 70 & At site & $\mathrm{D}$ & 33.100 & -91.253 & 3.87 & 0.91 & 0.52 & 0.21 & 0.20 & 0.21 & 1.67 \\
\hline 71 & Border & $\mathrm{D}$ & 33.006 & -91.266 & -1.63 & -5.82 & -6.86 & -8.12 & -8.60 & -9.04 & -8.77 \\
\hline 72 & $10 \%$ & $\mathrm{D}$ & 33.110 & -91.251 & 0.51 & -3.09 & -3.93 & -4.78 & -5.12 & -5.35 & -5.16 \\
\hline 73 & $50 \%$ & $\mathrm{D}$ & 33.225 & -91.233 & 1.12 & 2.56 & 4.71 & 6.88 & 9.19 & 11.93 & 17.23 \\
\hline 74 & $85 \%$ & $\mathrm{D}$ & 33.315 & -91.334 & 1.45 & 2.88 & 5.38 & 8.15 & 10.62 & 13.00 & 19.17 \\
\hline
\end{tabular}



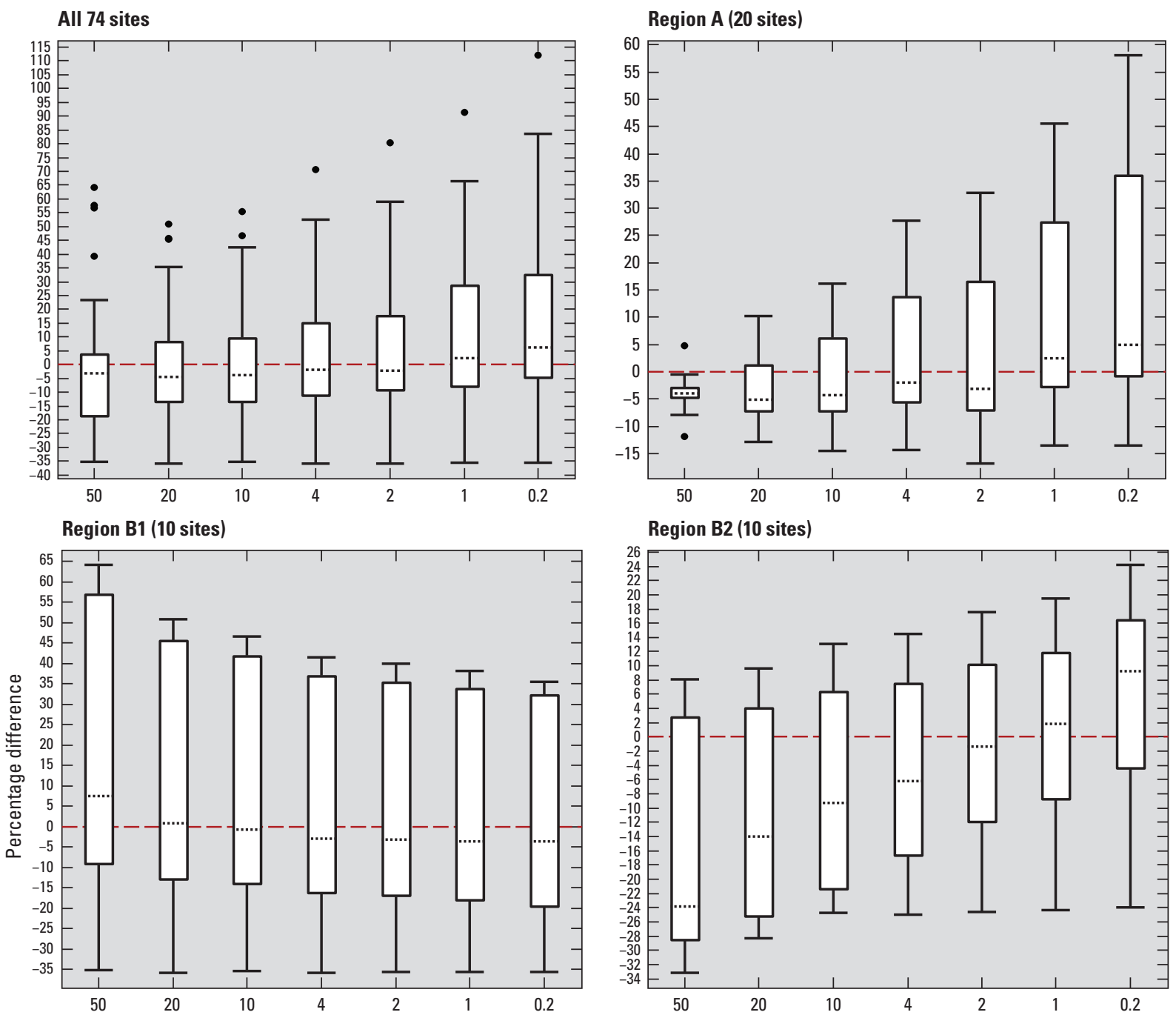

\section{Region C (24 sites)}

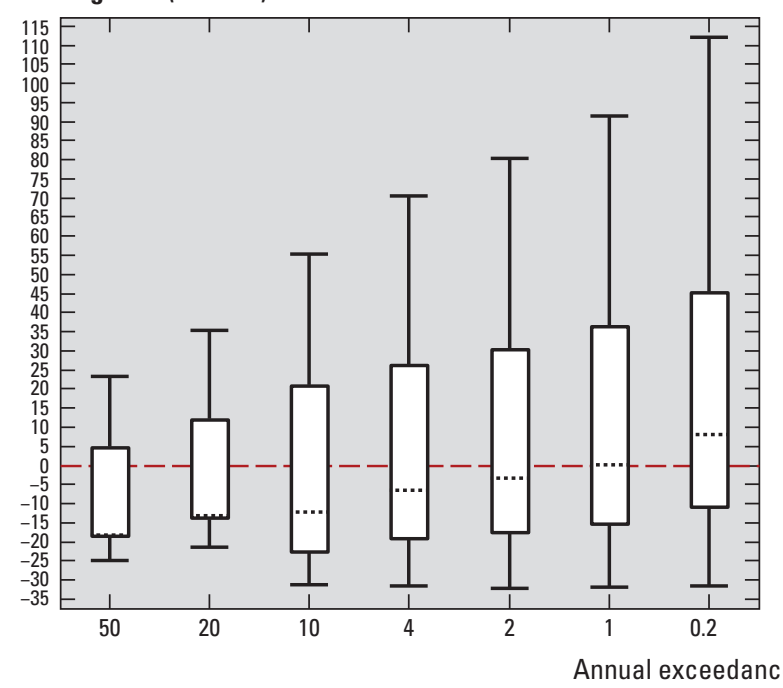

Region D (10 sites)

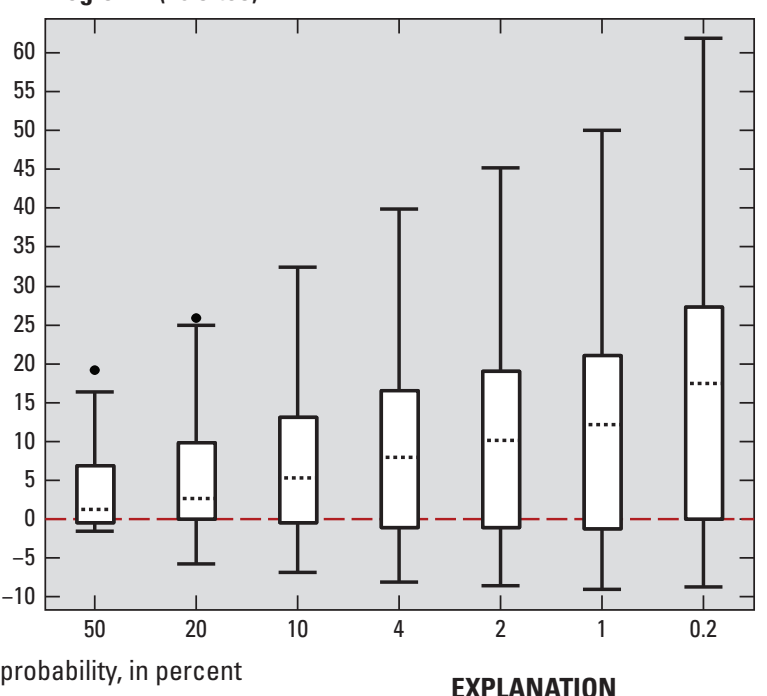

- Outlier (more than third quartile

Figure 6. The range of percentage differences of annual exceedance probability flood estimates from the 1995 to the 2016 regional regression equations by peak streamflow region as designated by Wagner and others (2016).

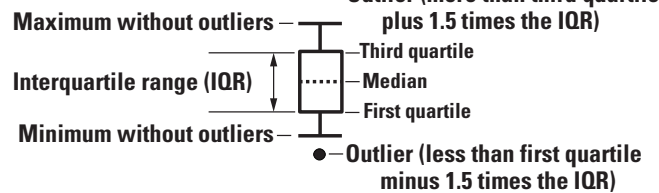


RI flood; table 3 ). The minimum PD of -35.9 percent was in region $\mathrm{B} 1$ at the 85-percent location at Cossatot River near Vandervoort (USGS station 07340300, site 10 in fig. 1 and sites 45-49 in fig. 2) for the 20-percent AEPF (5-year RI flood) (table 3).

\section{Summary}

Concerns exist in Arkansas regarding possible increasing trends in annual peak streamflow and the resulting increase in annual exceedance probability flood (AEPF) estimates. An increasing peak streamflow trend would correspond to an increased flood risk to highway structures and surrounding communities. To address these concerns, the U.S. Geological Survey, in cooperation with the U.S. Army Corps of Engineers and the Federal Emergency Management Agency, completed a study in Arkansas to determine if significant increasing trends exist in annual peak streamflow data. The Mann-Kendall trend test was used to identify possible trends at 15 selected streamgages in Arkansas. Using the full period of record, results from the Mann-Kendall trend test indicate that 1 of the 15 streamgages had a significantly decreasing trend and the remaining 14 streamgages had no statistically significant trends. The full period-of-record trend analysis may obscure trends that may exist within peak streamflow data of a shorter duration; therefore, a locally estimated scatterplot smoothing trend line using a span window of 0.75 was used to visually explore for trends within peak streamflow data. The locally estimated scatterplot smoothing trend line generally indicated an increasing trend in the peak streamflow since the 1990s at 8 of the 15 streamgages.

The percentage differences (PDs) between AEPFs from the 1995 and 2016 Arkansas flood-frequency reports were calculated and compared. A summary of the PDs between the 1995 and 2016 AEPFs was derived for the 50-, 20-, 10-, 4-, 2-, 1-, and 0.2-percent AEPFs. This analysis was completed at the 15 selected streamgages and at the percent locations along the streams associated with these streamgages. The AEPFs for the 0-, 10-, 50-, and 85-percent locations along the 15 streams were computed using the regional regression equations from the 1995 and 2016 flood-frequency reports. A total of 74 locations consisting of streamgage locations and percent locations along the streams were evaluated for PDs between the 1995 and 2016 regional regression equations. The PDs between the 1995 and 2016 AEPFs indicate that the 2016 AEPFs estimated larger floods for the 4-, 2-, 1-, and 0.2-percent AEPFs by 3.52, 5.10, 8.59, and 13.31 percent, respectively. The PDs between the 1995 and 2016 AEPFs were similar for the 10- and 20-percent AEPFs with only 0.41 and 0.31 PDs, respectively; however, the PDs between the 1995 and 2016 AEPFs indicate that the 1995 regional regression equations estimated larger floods for the 50-percent AEPFs by 2.53 percent and vary between flood regions across Arkansas.

\section{References Cited}

Cleveland, W.S., Devlin, S.J., and Grosse, E., 1988, Regression by local fitting-Methods, properties, and computational algorithms: Journal of Econometrics, v. 37, no. 1, p. 87-114. [Also available at https://doi.org/10.1016/03044076(88)90077-2.]

Cleveland, W.S., Grosse, E., and Shyu, W.M., 1992, Local regression models, chap. 8 of Chambers, J.M., and Hastie, T.J., eds., Statistical models in S: Pacific Grove, Calif., Wadsworth \& Brooks/Cole Advanced Books and Software, p. 309-376.

Cohn, T.A., England, J.F., Berenbrock, C.E., Mason, R.R., Stedinger, J.R., and Lamontagne, J.R., 2013, A generalized Grubbs-Beck test statistic for detecting multiple potentially influential low outliers in flood series: Water Resources Research, v. 49, no. 8, p. 5047-5058. [Also available at https://doi.org/10.1002/wrcr.20392.]

Cohn, T.A., Lane, W.L., and Baier, W.G., 1997, An algorithm for computing moments-based flood quantile estimates when historical flood information is available: Water Resources Research, v. 33, no. 9, p. 2089-2096. [Also available at https://doi.org/10.1029/97WR01640.]

Cohn, T.A., Lane, W.L., and Stedinger, J.R., 2001, Confidence intervals for Expected Moments Algorithm flood quantile estimates: Water Resources Research, v. 37, no. 6, p. 1695-1706. [Also available at https://doi. org/10.1029/2001WR900016.]

Cohn, T.A., and Lins, H.F., 2005, Nature's style-Naturally trendy: Geophysical Research Letters, v. 32, no. 23, L23402, 5 p. [Also available at https://doi. org/10.1029/2005GL024476.]

Fenneman, N.M., and Johnson, D.W., 1946, Physiographic divisions of the conterminous U.S.: U.S. Geological Survey map, accessed July 12, 2017, at https:/water.usgs.gov/ lookup/getspatial?physio.

Griffis, V.W., Stedinger, J.R., and Cohn, T.A., 2004, Log Pearson type 3 quantile estimators with regional skew information and low outlier adjustments: Water Resources Research, v. 40, no. 7, W07503, 17 p. [Also available at https://doi.org/10.1029/2003WR002697.]

Helsel, D.R., and Hirsch, R.M., 2002, Statistical methods in water resources: U.S. Geological Survey Techniques of Water-Resources Investigations, book 4, chap. A3, 522 p., accessed December 2017 at https://doi.org/10.3133/ twri04A3. 
Hirsch, R.M., 2011, A Perspective on nonstationarity and water management: Journal of the American Water Resources Association, v. 47, no. 3, p. 436-446. [Also available at https://doi.org/10.1111/j.1752-1688.2011.00539.x.]

Hodge, S.A., and Tasker, G.D., 1995, Magnitude and frequency of floods in Arkansas: U.S. Geological Survey Water-Resources Investigations Report 95-4224, 52 p. [Also available at https://doi.org/10.3133/wri954224.]

Holmes, R.R., Jr., and Dinicola, K., 2010, 100-year flood-It's all about chance: U.S. Geological Survey General Information Product 106, 1 p. [Also available at https://doi. org/10.3133/gip106.]

Interagency Committee on Water Data, 1982, Guidelines for determining flood flow frequency: Interagency Advisory Committee on Water Data, Bulletin 17B of the Hydrology Subcommittee, 183p. [Also available at https://water.usgs. gov/osw/bulletin17b/dl_flow.pdf.]

Kundzewicz, Z.W., and Robson, A.J., 2004, Change detection in hydrological records - A review of the methodology: Hydrological Sciences, v. 49, no. 1, p. 7-19. [Also available at https://doi.org/10.1623/hysj.49.1.7.53993.]

Lins, H.F., and Cohn, T.A., 2011, Stationarity-Wanted dead or alive?: Journal of the American Resource Association, p. 475-480. [Also available at https://doi.org/10.1111/ j.1752-1688.2011.00542.x.]

Milly, P.C., Betancourt, D.J., Falkenmark, M., Hirsch, R.M., Kundzewicz, Z.W., Lettenmaier, D.P., and Stouffer, R.J., 2008, Stationarity is dead-Whither water management?: Science, v. 319, no. 5863, p. 573-574. [Also available at https://doi.org/10.1126/science.1151915.]

Pugh, A.L., and Westerman, D.A., 2014, Mean annual, seasonal, and monthly precipitation and runoff in Arkansas, 1951-2011: U.S. Geological Survey Scientific Investigations Report 2014-5006, 40 p., accessed May 2017 at https://doi.org/10.3133/sir20145006.
R Core Team, 2016, R-The R project for statistical computing: Vienna, Austria, The R Foundation for Statistical Computing. [Also available at https://www.R-project.org/.]

U.S. Geological Survey, 2016, USGS water data for the Nation: U.S. Geological Survey National Water Information System database, accessed October 1, 2016, at https://doi. org/10.5066/F7P55KJN.

Veilleux, A.G., 2009, Bayesian GLS regression for regionalization of hydrologic statistics, floods, and Bulletin 17B skew: Cornell, N.Y., Cornell University, master's thesis, 170 p. [Also available at https://hdl.handle.net/1813/13819.]

Veilleux, A.G., 2011, Bayesian G1S regression, leverage, and influence for regionalization of hydrologic statistics: Cornell, N.Y., Cornell University, Ph.D. dissertation, 199 p. [Also available at https://hdl.handle.net/1813/30607.]

Veilleux, A.G., Cohn, T.A., Flynn, K.M., Mason, R.R., Jr., and Hummel, P.R., 2014, Estimating magnitude and frequency of floods using the PeakFQ 7.0 program: U.S. Geological Survey Fact Sheet 2013-3108, 2 p., accessed January 2017 at https://doi.org/10.3133/fs20133108.

Wagner, D.M., Krieger, J.D., and Veilleux, A.G., 2016, Methods for estimating annual exceedance probability streamflows for streams in Arkansas, based on data through water year 2013: U.S. Geological Survey Scientific Investigations Report 2016-5081, 31 p., accessed January 2017 at https:// doi.org/10.3133/sir20165081.

Walter, M., and Vogel, R.M., 2010, Increasing trends in peak flows in the northeastern United States and their impacts on design: 2d Joint Federal Interagency Conference, Las Vegas, Nev., June 27-July 1, 2010, 16 p., accessed April 2017 at https://acwi.gov/sos/pubs/2ndJFIC/Contents/2F_ Walter_03_01_10.pdf. 
For more information about this publication, contact: Director, Lower Mississippi-Gulf Water Science Center U.S. Geological Survey

640 Grassmere Park, Ste 100

Nashville, TN 37211

615-837-4700

For additional information, visit: https://www.usgs.gov/centers/lmgwater

Publishing support provided by the

Rolla Publishing Service Center 
